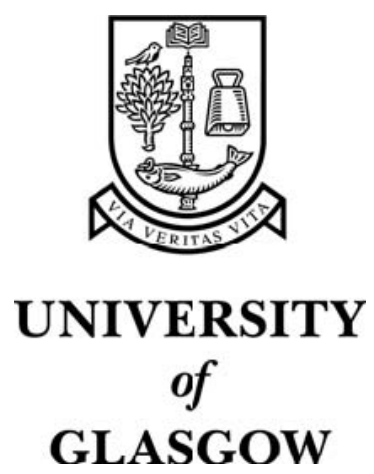

Jansen, J. D. and Brierley, G. J. (2004) Pool-fills: a window to palaeoflood history and response in bedrock-confined rivers. Sedimentology 51(5):pp. 901-925.

http://eprints.gla.ac.uk/3397/ 


\title{
Pool-fills: a window to palaeoflood history and response in bedrock-confined rivers
}

\author{
JOHN D. JANSEN ${ }^{* 1}$ and GARY J. BRIERLEY $\dagger$ \\ * School of Geosciences, University of Wollongong, Wollongong, 2522, NSW, Australia \\ $\dagger$ Department of Physical Geography, Macquarie University, Sydney, 2109, NSW, Australia
}

\begin{abstract}
Channel-scale sedimentary units associated with bedrock-controlled rifflepool morphology are examined in detail along Sandy Creek gorge, an ephemeral stream in arid south-eastern central Australia. Pool-fills comprise cut-and-fill assemblages of poorly sorted sediments ranging in texture from muds to boulders. Five unit types are defined based on particle size, sedimentary structures, geometry and bounding surface character: (1) coarsegrained bar platform; (2) fine-grained bar supraplatform; (3) fine-grained poolfill; (4) fine-grained bench; and (5) modern pool-fill. The last coarse-grained unit currently lining the pools suggests an altered sedimentation style over the post-settlement period (post-AD 1860s). Situated at bedrock valley constrictions, pool-fills are compared with other sedimentary units associated with recirculating currents: eddy bars and slackwater deposits. But only the fine-grained bench units reflect eddy recirculation; the pool-fills are principally forced-bars associated with bedrock-controlled or 'forced' rifflepool morphology. A late Holocene palaeoflood history is proposed based on radiocarbon ages from the pool-fills: multiple phases of cut-and-fill activity were preceded by a superflood 3400-1900 years ago that eroded the pool-fills to bedrock. The resilience of the pool-fills was illustrated by the passage of a 1-in-100-year flood in 1992, which caused only minor erosion. The presence of pool-fills may provide a window to past phases of river activity that cannot be extracted from either historical records/observations or palaeoflood slackwater sediment analyses. The formation and sedimentary preservation potential of these landforms reflect a combination of hydraulic and structural influences, but the occurrence of high-magnitude floods exerts the dominant control.
\end{abstract}

Keywords Bench, late Holocene, palaeoflood, pool-fill stratigraphy, preservation potential, riffle-pool.

\section{INTRODUCTION}

Understanding the contemporary behaviour and history of bedrock-confined rivers is rendered difficult by the episodic reworking of temporary sedimentary fills, which generally leaves little alluvial record to investigate. Channel forms in bedrock valleys tend to reflect the work of floods

\footnotetext{
${ }^{1}$ Present address: Centre for Geosciences, University of Glasgow, Glasgow G12 8QQ, UK (E-mail: jjansen@ geog.gla.ac.uk)
}

of multidecadal frequency (O'Connor et al., 1986; Grant et al., 1990; Chin, 1998), but superfloods episodically destroy alluvial sequences (Stewart \& LaMarche, 1967; Schick, 1974; Baker, 1977). The magnitude and frequency of large prehistoric floods along bedrock valleys is conventionally gleaned from analysis of slackwater sedimentation at suitable sites that include recirculating currents, or backwater effects of flow constrictions downstream (e.g. Patton et al., 1979; Baker, 1984; Kochel \& Baker, 1988; Pickup et al., 1988; O’Connor et al., 1994). However, such analyses rarely reveal the full spectrum of formative 
flood magnitudes, and this approach fosters a perception of flood histories as a string of big floods 'interrupting long periods of nothing much in particular' (Ager, 1973, p. 93). Little is known of bedrock river behaviour over the long intervals of relative quiescence between the catastrophic floods that either deposit or flush out temporary stores of alluvium. Ironically, because extreme floods occur infrequently, such intervals represent the norm. It is proposed here that a measure of river behaviour over these intervals may be gained via analysis of pool-fills: channel-scale sedimentary units associated with riffle-pool morphology, which provide a potential window to largely overlooked phases of river activity.

This paper examines the sedimentology and stratigraphy of a series of pool-fills along a bedrock-confined ephemeral stream in arid south-eastern central Australia. The pool-fills are compared with other sedimentary units associated with recirculating currents: eddy bars and slackwater deposits. Fluvial processes responsible for the formation, preservation and destruction of pool-fills are discussed together with the use of these features in providing information on the intermediate-magnitude floods that shape river morphology in bedrock-confined valleys. Pool-fill assemblages are associated with bedrock valley bends and constrictions and comprise cut-and-fill sequences of poorly sorted sediments ranging in texture from mud to boulders. Although the concentration of scour through pools during large floods imparts a low preservation potential to pool-fills over geological timescales, the examples presented here represent substantial storage terms (up to $10^{3}$ a).

\section{Channel forms in bedrock-confined rivers}

Riffles and pools are widely described from bedrock-confined rivers of low to moderate gradient $(<0 \cdot 015)$. Their origin and maintenance are held to involve a combination of hydraulics and structural influences that constrict flow, such as resistant rock, tributary fans, talus inputs or large woody debris, factors additional to riffle-pools in alluvial channels (Dolan et al., 1978; Keller \& Melhorn, 1978; Graf, 1979; Howard \& Dolan, 1981; Kieffer, 1985, 1989; Lisle, 1986; O’Connor et al., 1986; Wohl et al., 1993; Miller, 1994; Montgomery \& Buffington, 1997; Thompson, 2001). Riffles and pools formed in the coarse bed materials lining most bedrock rivers are commonly positioned relative to the pattern of thalweg switching between alternate valley margins, a pattern known as 'forced' riffle-pool morphology (e.g. Montgomery \& Buffington, 1997), and the distribution of stream power during large floods has been shown to be an important control. Deposition associated with flow divergence at boulder riffles corresponds to stream power minima, while convergent flow maximizes stream power at pools (O'Connor et al., 1986; Wohl, 1992a,b; Wohl et al., 1994).

Carling (1987, 1989, 1995) replicated field observations in flume experiments demonstrating boulder berm formation resulting from flow separation and hydraulic jumps at expansions in straight channels. However, no similar work details the morphodynamics of sharp, nondeformable bends in high-energy rivers. Sharp bedrock bends host superelevated flows, and steep transverse slopes favour strong secondary flow structures, which in turn exert control on sedimentation. It is thought that an intense and persistent type of vortex scour develops near the bed with a horizontal axis resulting in local bed scour and deflection of bedload away from the outer bedrock channel boundary (Lisle, 1986; Mlynarczyk \& Rotnicki, 1989). The resultant coarse-grained forced-bar or point-bench (Hickin, 1969) on the inside of the bend forms a slip face that is analogous to the point-bar slip face in alluvial channels; this is accompanied by a scour hole on the outside of the bend abutting the bedrock boundary. As bedrock bends are persistent features, it is reasoned that the forced-bars associated with them may be highly stable (Dury, 1970; Kinoshita \& Miwa, 1974).

Lateral bar-forms associated with pools in gravel- and mixed-bed streams are widely recognized (e.g. Bowman, 1977; Keller \& Melhorn, 1978; Jackson \& Beschta, 1982; Lisle, 1986, 1999; Pickup, 1986; Lisle \& Hilton, 1992). These forms bear attributes of a number of channel-scale sedimentary deposits associated with flow separation including concave-bank benches (Page \& Nanson, 1982), in-channel benches (Erskine \& Livingstone, 1999), forced-bars (Kinoshita \& Miwa, 1974; Montgomery \& Buffington, 1997) and eddy bars (Baker et al., 1983; Baker, 1984). Eddy bars have been studied extensively in Grand Canyon where flow separation is generated at expansions downstream of tributary debris fans (e.g. Howard \& Dolan, 1981; Rubin et al., 1990; Schmidt, 1990; Schmidt \& Graf, 1990; Schmidt et al., 1993; Schmidt \& Rubin, 1995; Cenderelli \& Cluer, 1998). Pool-fills are compared with these well-studied, partly analogous deposits, as discussed below. 
Figure 1a illustrates a frequently observed pattern in which variable valley morphology interacts with large-flood hydraulics to shape the distribution of fluvial landforms such as riffles and pools, with coarse-grained floodplains along expanded sections of the valley floor. Figure $1 \mathrm{~b}$ presents a simple qualitative model of pool in-filling and flushing responses to low- and high-magnitude floods respectively.

Until now, analyses of pool-fills have been framed relative to channel hydraulics linked to sediment transport (Jackson \& Beschta, 1982), or as indicators of fine-sediment supply conditions in gravel-bed streams (Lisle \& Hilton, 1992; Lisle, 1999). Lisle \& Hilton (1992) developed a model of pool filling in which progressive sedimentation occurs along the pool exit slope and, in their analysis of the flow hydraulics of pools abutting bedrock obstructions, Thompson et al. (1999) determined that pool exit slopes strongly influence the development of hydraulic jetting and recirculating eddies. However, the frequency of flood magnitudes required to scour pool-fills has not been investigated, and this aspect of rifflepool channels remains poorly understood (Thompson et al., 1999). While efforts to characterize sorting patterns in riffle-pool bed sediments have met with difficulties in discriminating between populations associated with known flow conditions (e.g. Richards, 1976; Jackson \& Beschta, 1982), the potential to gain flood information from stratigraphic analysis of pool-fills remains unknown. Apart from Bowman's (1977) study of stepped-bed morphology in the Negev, work on pool-fills has been largely restricted to perennial streams, which are difficult to excavate effectively (e.g. Lisle \& Hilton, 1992; Lisle, 1999).

\section{SANDY CREEK}

The Sandy Creek study area is located on the north-east flank of the Barrier Range, $100 \mathrm{~km}$ north of Broken Hill in far western New South Wales (31 $00^{\prime}$ S, $141^{\circ} 45^{\prime}$ E; Fig. 2). Mean annual rainfall at nearby Fowlers Gap is $243 \mathrm{~mm}$ ( $\pm 118 \mathrm{~mm}$ standard deviation), and pan evaporation is about $2800 \mathrm{~mm}$ (Bureau of Meteorology, 1988). Flow data from an adjoining $20 \mathrm{~km}^{2}$ catchment, Homestead Creek, reveal an extreme index of flow variability of 0.92 (i.e. the standard deviation of the logarithms of the annual flood peaks), which is probably representative of streams in the region.

Sandy Creek is a fourth-order ephemeral stream draining $44 \mathrm{~km}^{2}$ of steeply dissected uplands. Gently dipping Devonian sandstones - mostly fine- to very fine-grained quartzose arenites (Neef et al., 1995) - form broad cuestas standing 100$200 \mathrm{~m}$ above the flanking piedmont and Bancannia Plain. Wide tributary strike valleys, cut in relatively weak rocks, are interspersed by resistant strata that form the axes of cuesta ridges and main-stem valley constrictions. Figure 3 shows
Fig. 1. (a) Schematic bedrock-confined river planform. Resistant bedrock bisects the valley floor yielding 'forced' riffle-pool morphology, with shallow, coarse-grained floodplains developed along broader sections cut in weaker rocks. (b) Schematic cross-section $\left[\mathrm{A}-\mathrm{A}^{\prime}\right.$ in $\left.(\mathrm{a})\right]$ showing pool-fill cyclicity in response to erosional and depositional episodes. The progression of forms indicated is qualitative only; the direction of change depends upon the occurrence and magnitude of floods through time. The passage of a superflood may erode the pool assemblages to bedrock at any time. (a)

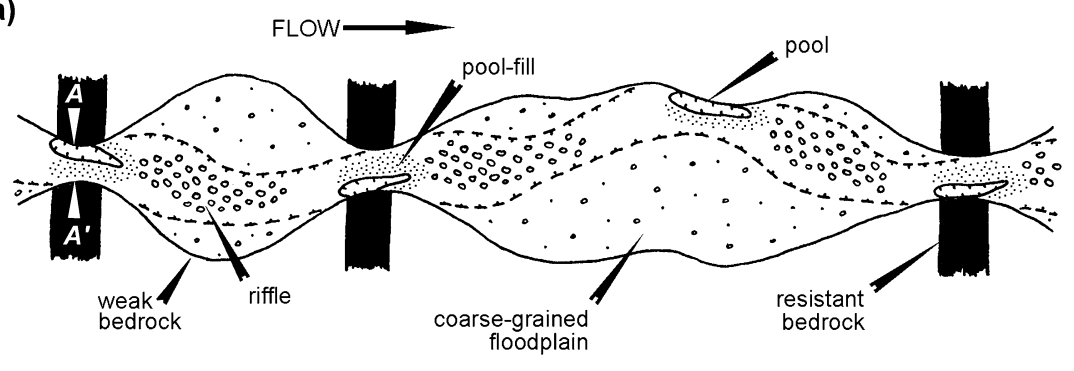

(b)

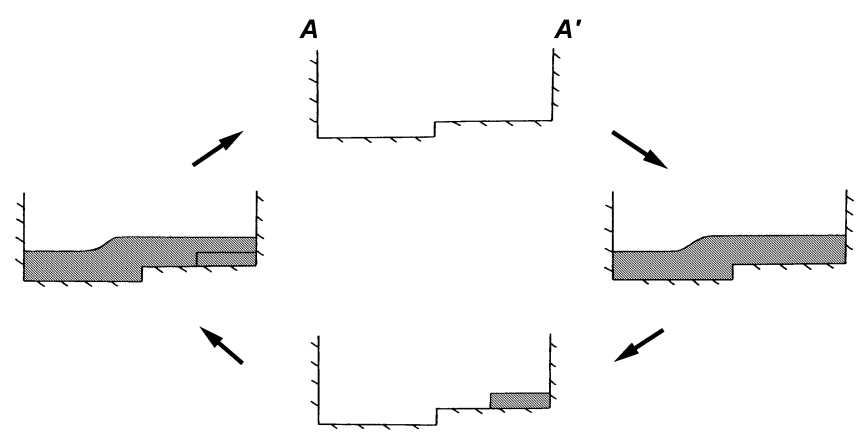




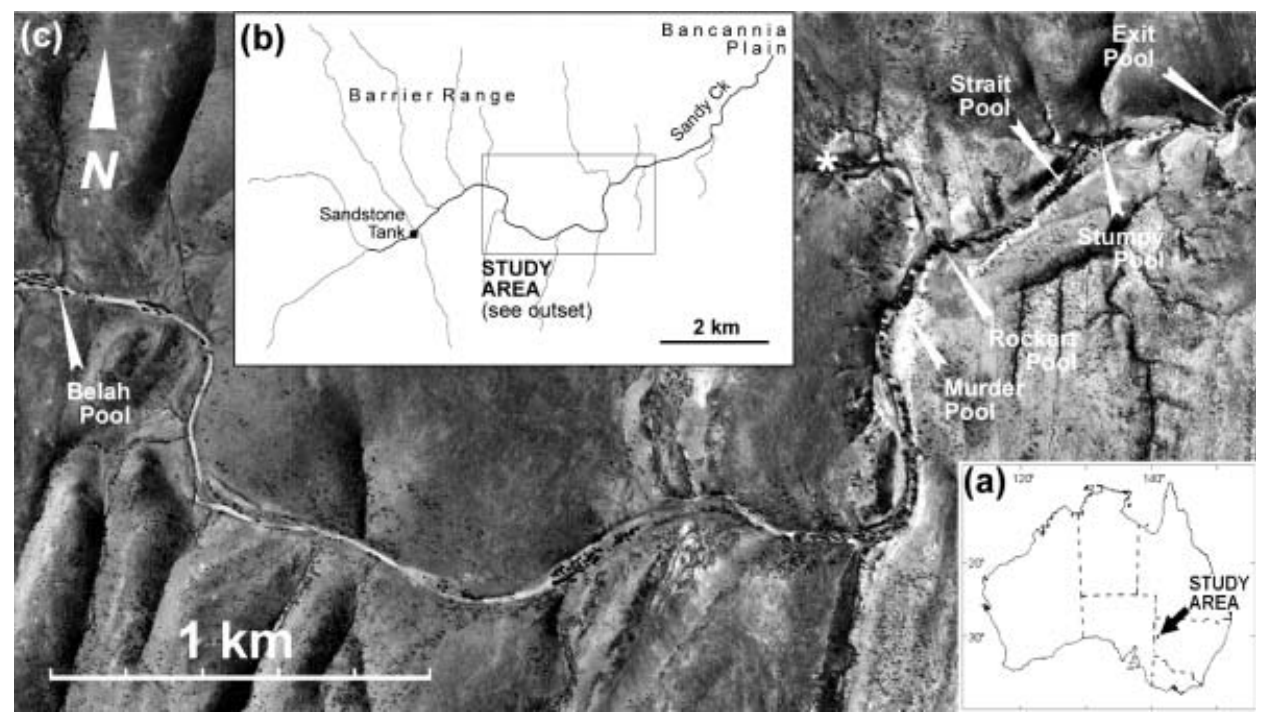

Fig. 2. (a) Study area location within south-eastern central Australia; (b) positioning within the Sandy Creek catchment; and (c) sites of the pool-fills excavated and studied. Flow is overall west-to-east. The white asterisk on the left-bank tributary creek marks the site of a dated Aboriginal hearth referred to in the text (Wk-4102).

how major constrictions in valley width correspond to resistant Devonian strata.

This study focuses on the lower $1.6 \mathrm{~km}$ of the gorge over a sequence of five pools and five riffles (Figs 3 and 4). Reach bed slope is $0 \cdot 0087$, and bedrock channel width ranges between 30 and

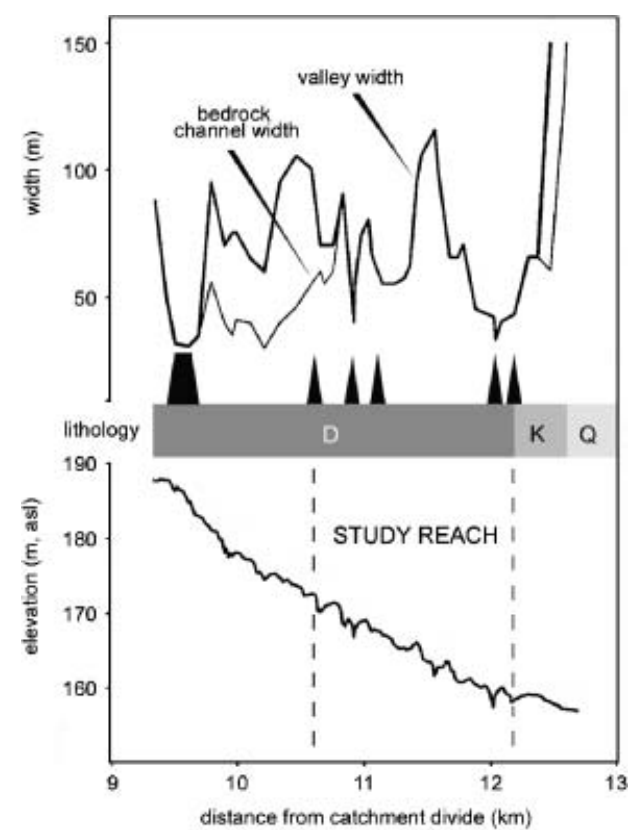

Fig. 3. Downstream relations between valley and (inner) bedrock channel width, lithology and channel gradient. Lithology symbols denote Quaternary sediments (Q), Devonian sandstone (D) and Cretaceous strata (K). Resistant Devonian strata (heavy black triangles) mark major valley constrictions.
$115 \mathrm{~m}$. Coarse bed materials line much of the channel, although mixed bedrock-alluvial sections occur: $27 \%$ of the thalweg is floored with bedrock, and the alluvial veneer rarely exceeds $2 \mathrm{~m}$ in thickness. The pools range between $1 \cdot 0$ and $2.7 \mathrm{~m}$ in residual depth and 70 and $130 \mathrm{~m}$ in length, and are best developed at constricted bedrock bends where they function as a series of nozzles during large floods (Fig. 5) interspersed by expansion bars capped with bouldery riffle crests (Baker, 1984; Kieffer, 1985; Miller, 1994). The largest fluviatile boulders comprising the riffle crests are up to $2 \mathrm{~m}$ in diameter $\left(d_{50}=208 \mathrm{~mm}, d_{84}=690 \mathrm{~mm}, d_{95}=1070 \mathrm{~mm}\right.$, averaged over the coarse locales of the five riffles), and these tend to grade laterally into a narrow, coarse-grained floodplain. Figure 6 illustrates a common pattern in which a pool-fill bench is inset between a coarse-grained floodplain and pool, signifying that bench development reflects processes of channel contraction.

In many of the world's drylands, humaninduced biogeomorphological changes rival those caused by large-scale climate shifts over the Late Quaternary (Wainwright et al., 1999). In the Barrier Range, it is widely recognized that major shifts in vegetation community structure and composition have occurred since European pastoralism first expanded into the region in the 1860s (e.g. Beadle, 1948; Wasson \& Galloway, 1986; Fanning, 1999). Trees were cut extensively to provide for fences, firewood and drought fodder. Based on fencing needs alone, by 1908, 


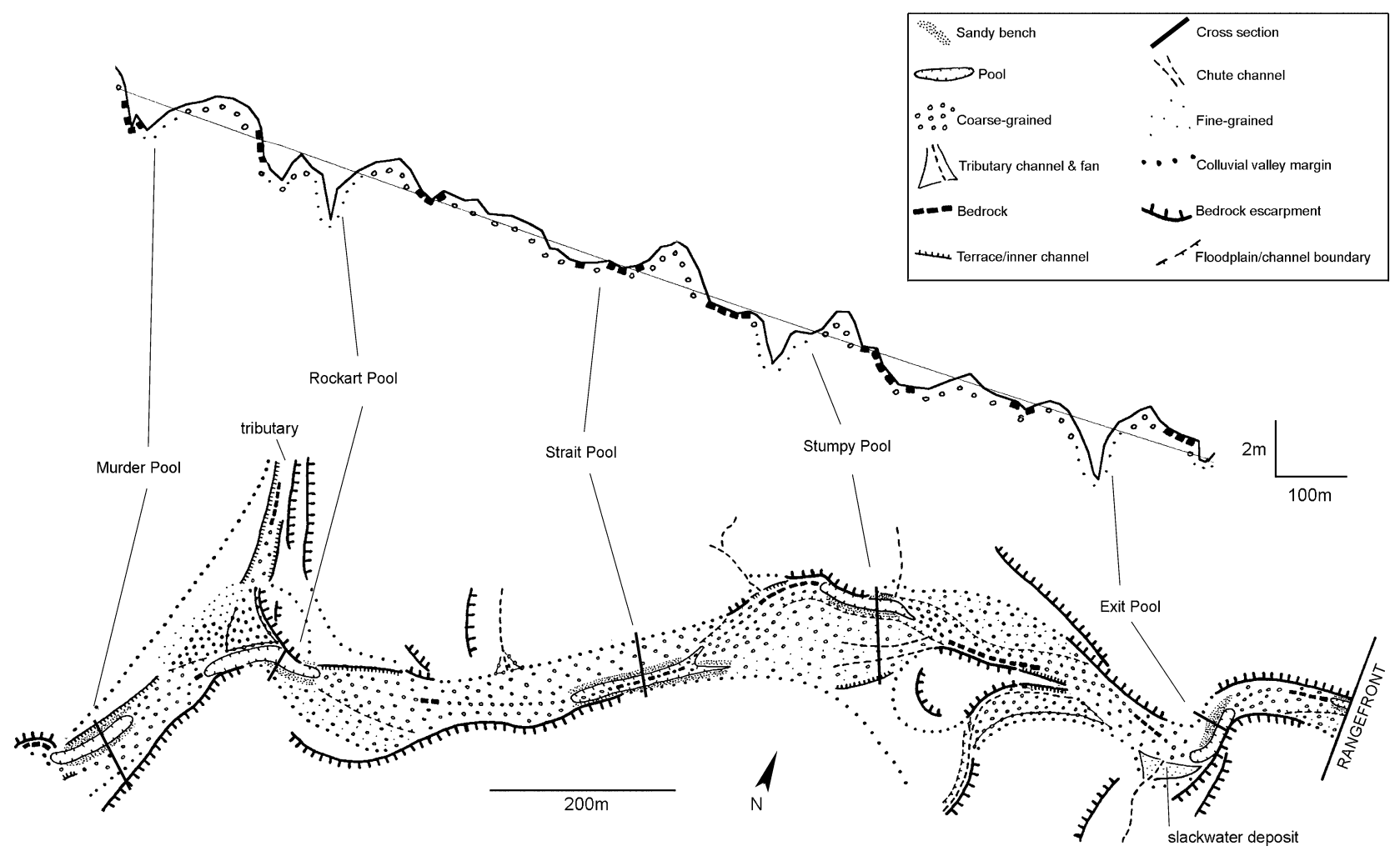

Fig. 4. Study reach planform and longitudinal profile. A second-order polynomial curve fitted to the longitudinal profile adequately delineates riffles and pools as positive and negative residuals respectively (Richards, 1976). Note pools pinned at bedrock margins.

136 trees $\mathrm{km}^{-2}$ had been destroyed across the Sandy Creek catchment (Jansen, 2001). The growth of large in-channel trees, such as river red gums (Eucalyptus camaldulensis), greatly affects hydraulic roughness, sedimentation and reinforcement of alluvium along ephemeral streams of arid Australia (Dunkerley, 1992; Graeme \& Dunkerley, 1993). The river red gums were largely spared, but the pools in Sandy Creek are otherwise bare of vegetation because of ongoing grazing pressures and the poor moisture-holding capacity of the gravelly sands lining the pools. Judging by observations of pools in less disturbed sites elsewhere (e.g. Flinders Ranges, c. $320 \mathrm{~km}$ west), aquatic and riparian vegetation was probably far more prevalent in Sandy Creek before European pastoralism.

\section{METHODS}

\section{Field methods}

Bed material size characteristics along Sandy Creek gorge were determined by measuring 100 clasts at each riffle using Brierley \& Hickin's (1985) modified version of the Wolman (1954) method for measuring bed surface gravels. Pools along the gorge dry out completely after periods of no streamflow, permitting excavation of pool floors and banks. Six pool-fills were excavated (Fig. 2c) to reveal their internal stratigraphy: eight large pits (up to $10 \times 4 \times 1 \mathrm{~m}$ ), 20 minor pits and 16 auger holes. Pits were positioned in the centre of the pools, orthogonal to the thalweg.

The stratigraphic attributes were mapped in detail. Characteristic units were defined and used for lithostratigraphic correlation between exposures. The relative elevations of stratigraphic units were surveyed and incorporated into a network of valley-floor cross-sections. After initial description in the field, representative sediment samples were collected for laboratory analysis. A total of 81 bulk samples (300-500 g) was collected including at least three bed-surface samples from each pool $(n=35)$ and from stratigraphic units exposed in the pits $(n=46)$. Gravelly units were characterized in field outcrop only, although some fine-sediment matrix was sampled for particle-size analysis $(n=3)$. 


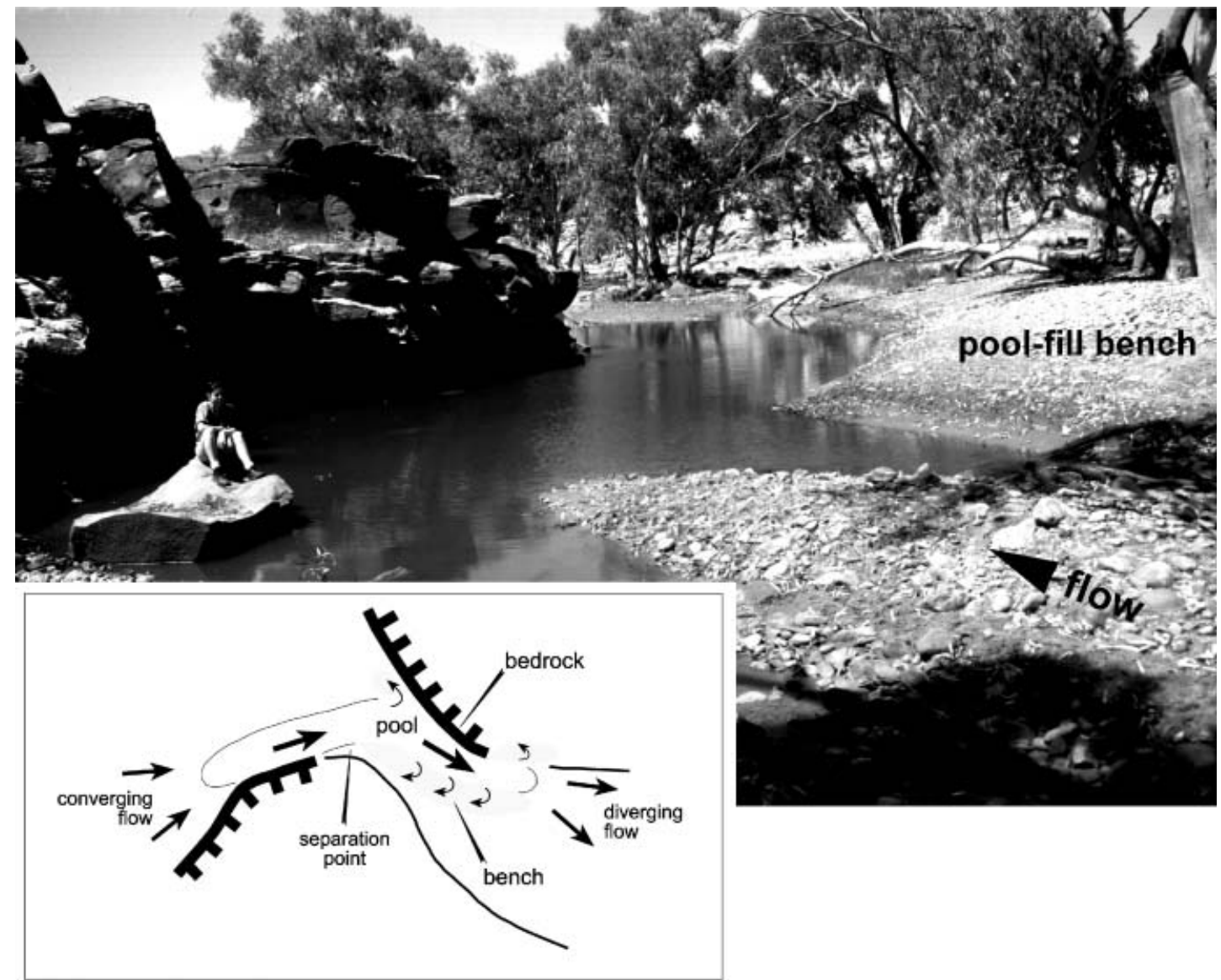

Fig. 5. Pool (Rockart Pool) developed where flow is deflected sharply at a bedrock bend. River red gums grow from the pool-fill bench at the right. The talus block fell from the bedrock face sometime between 1965 and 1991 . The inset represents the pool in planform, including zones of flow convergence and divergence, approximate eddy trajectories and the position of the separation point associated with the main bench pictured.

Dendrochronological methods have proved unsuccessful with river red gums because of their characteristically diffuse ring boundaries and intra-annual bands, which do not reflect seasonally regular growth (Ogden, 1978). In this study, a partially successful attempt was made to discern a relationship between tree diameter and age by recording the diameter and host sedimentary unit of all 517 trees along the study reach. However, as local moisture availability exerts considerable control on tree growth rate, excavations around 10 of the trees allowed better determination of the materials from which they were growing, and these data are used here.

\section{Laboratory methods}

Laboratory analyses aimed to discriminate quantitatively between the sedimentary units comprising the pool-fills. Munsell colour, particle lithology, shape and sorting were recorded along with the presence of aggregates, faecal pellets, organic matter and other detrital materials. Intact peds preserved within the older finesediment samples were examined under a binocular microscope to detect fine sedimentary structures, pedogenic fabrics and weathering features.

As subsample coefficients of variation tend to increase sharply for grains coarser than about $8 \mathrm{~mm}$ (Church et al., 1987), particles exceeding this size were noted (there were very few) and then manually removed along with macro-organic materials such as rootlets, stems and seeds. Each sample was split into subsamples with a riffle-box: $300 \mathrm{~g}$ splits for the bed-surface samples, and $85 \mathrm{~g}$ for the finer grained samples taken from the stratigraphic pits. These measures satisfy the 'adequate sample criterion' of Church et al. (1987). The subsamples were drysieved at $1 / 4 \Phi$ intervals to determine the proportion of gravel-sized particles $(2-8 \mathrm{~mm})$, and 


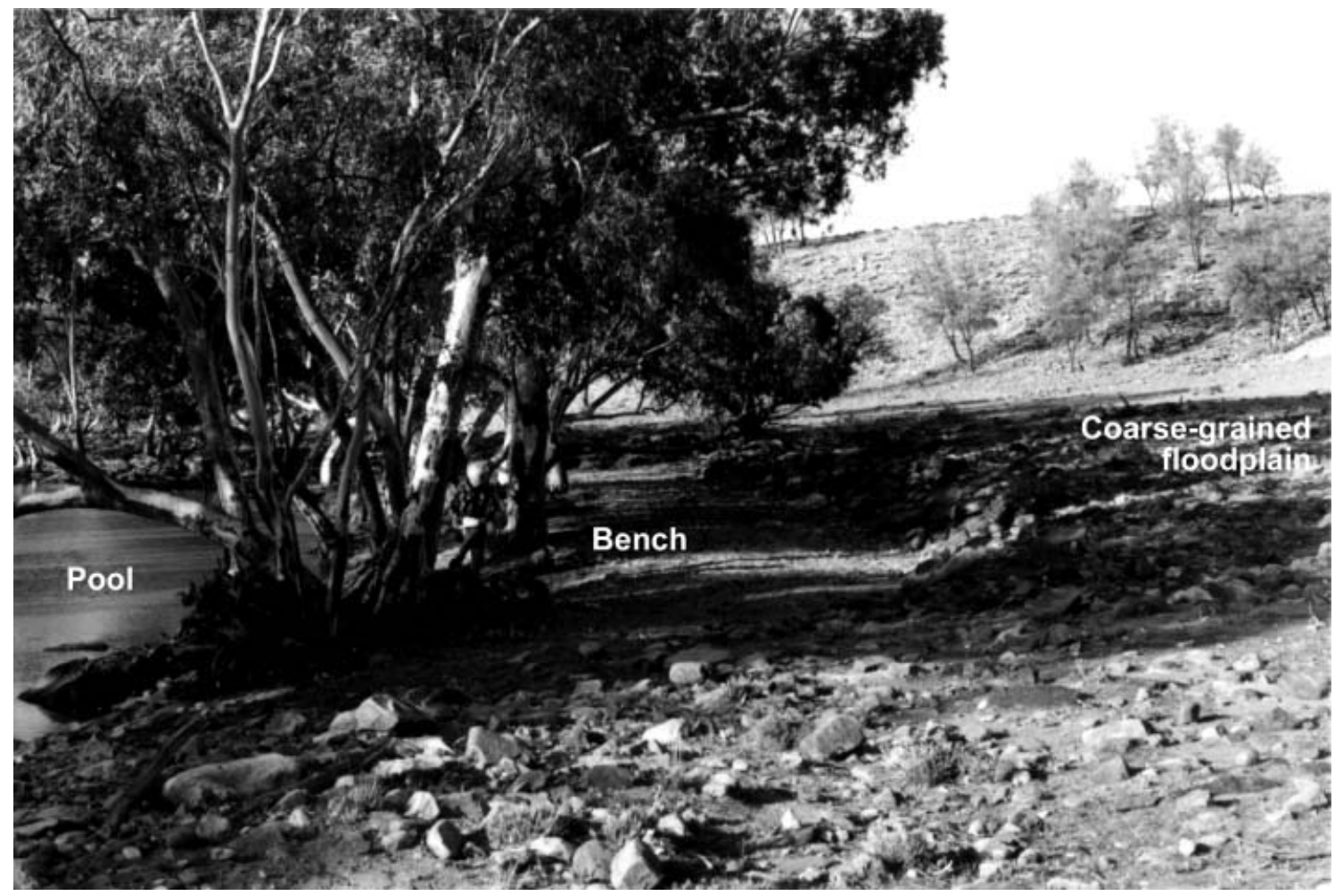

Fig. 6. The commonly observed inset positioning of pool-fill benches between a coarse-grained floodplain and pool (Murder Pool, downstream view). Large floods scour the pool-fills and trim the adjacent floodplain; subsequent bench sedimentation results in channel contraction.

wet-sieved following disaggregation and dispersion to determine the sand $(2-0.063 \mathrm{~mm})$ and mud $(<0.063 \mathrm{~mm})$ content.

\section{POOL-FILL SEDIMENTOLOGY}

\section{Pool unit types: definitions and attributes}

Sedimentary units exposed in the stratigraphic pits were delineated by particle size, sedimentary structures, geometry, bounding surface character, colour and weathering features (Brierley, 1991, 1996). Detailed stratigraphic sections of each pool are presented in Figure 7. Sedimentary units were generalized into five types, the primary attributes of which are summarized in Table 1. The first four types (viz. coarse-grained bar platform, finegrained bar supraplatform, fine-grained pool-fill and fine-grained bench) occur as stacked assemblages in the external form of an alluvial bench along one or both sides of the pools. The last type (viz. modern pool-fill) distinguishes channel sediments in contemporary transit through the pool troughs.

\section{Coarse-grained bar platform $\left(P_{c}\right)$}

These coarse-grained basal lag or bar-platform deposits (with clasts $8-400+\mathrm{mm}$ in diameter) comprise a very poorly sorted, clast- and/or matrix-supported framework with a coarse sand to granule matrix, indicating high-energy depositional environments. These units tend to exhibit concave-up or lenticular geometry and are often inclined channelwards. An erosional lower boundary, commonly bedrock, suggests flood scour and subsequent rapid deposition. The coarse basal-bar platform may constitute an erosional surface that is subject to repeated exposure and winnowing, or it may grade up to barsupraplatform deposits (Fig. 8). The long-term preservation of these deposits is enhanced by their coarse-grained nature and positioning in the base of the pool trough.

Fine-grained bar supraplatform $\left(P_{s}\right)$

These are fine-grained deposits (typically $>45 \%$ sand and $<1 \%$ gravel), usually greyish and very poorly sorted with some matrix-supported clasts. Generally massive or crudely upwardfining, these deposits feature ill-defined primary 
(a) Belah Pool

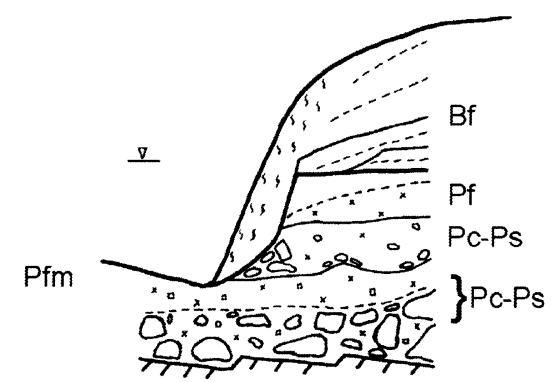

(b) Murder Pool

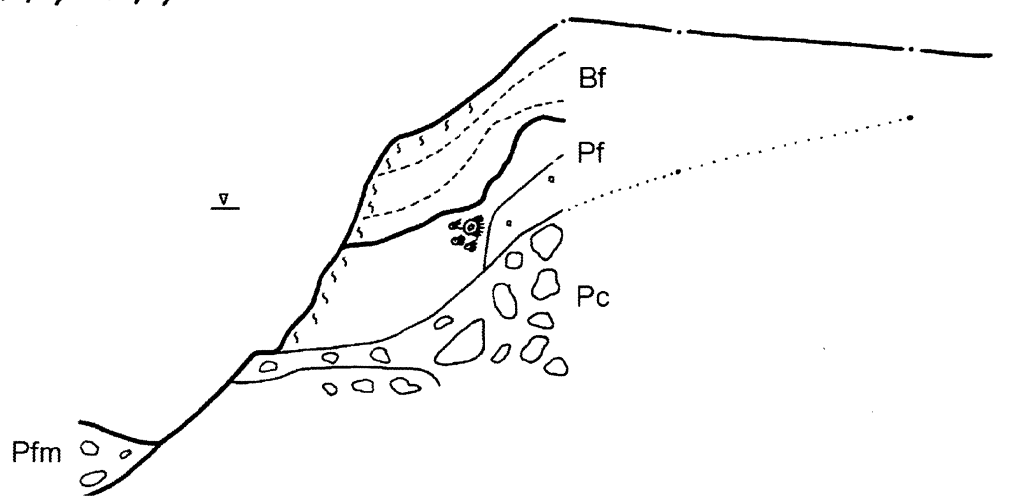

(c) Rockart Pool

$\pi$

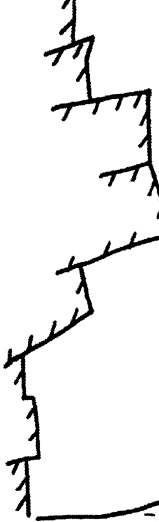

-

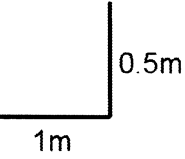


(d) Strait Pool left bank

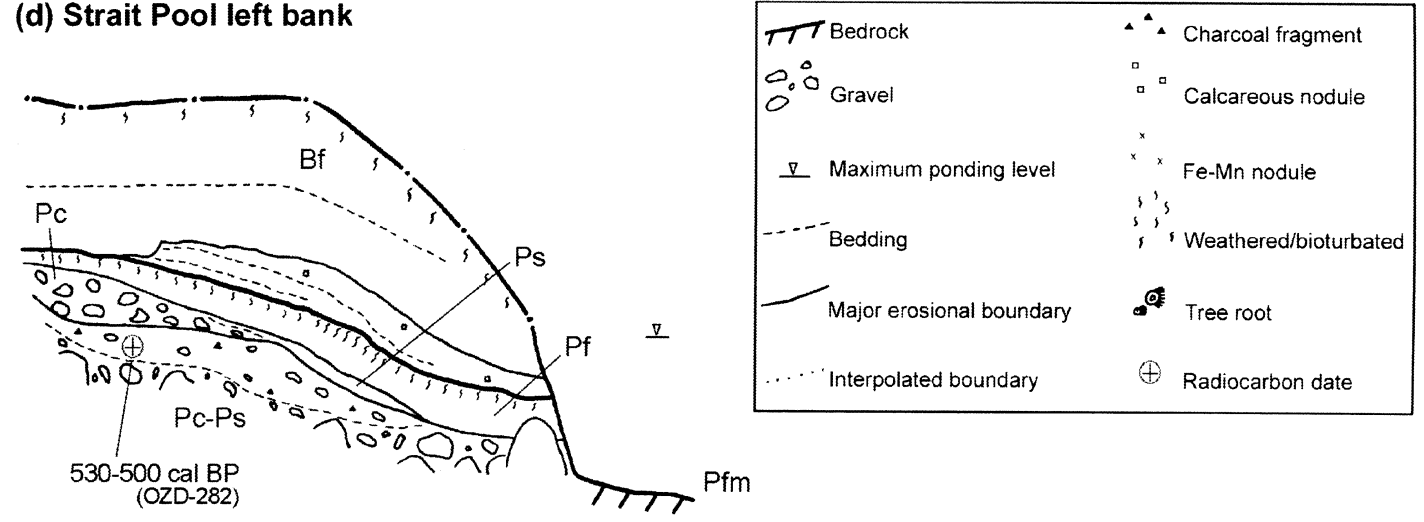

(e) Strait Pool right bank

$\underline{-}$

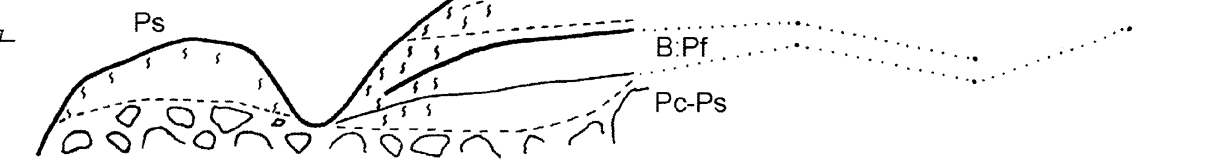

Pfm

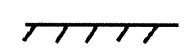

(f) Stumpy Pool left bank

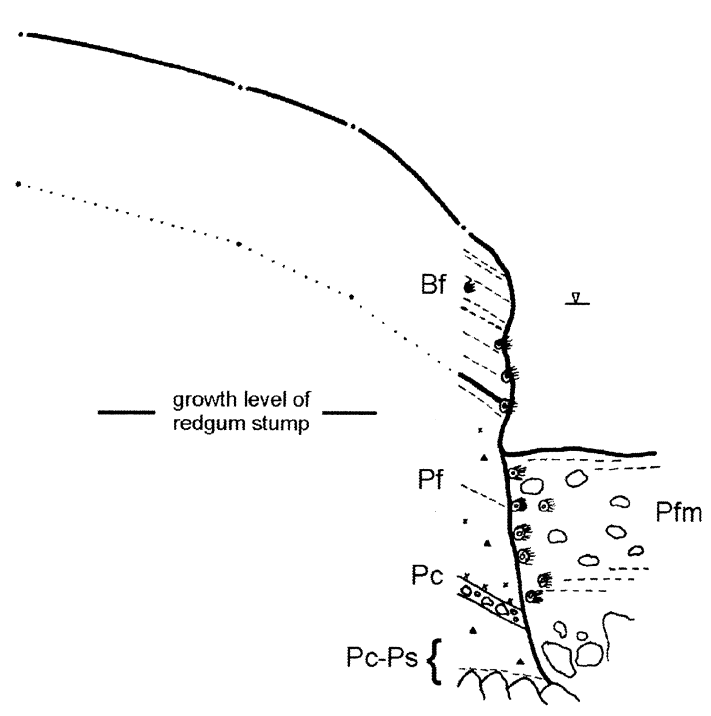

(g) Stumpy Pool right bank

Fig. 7. (Continued).

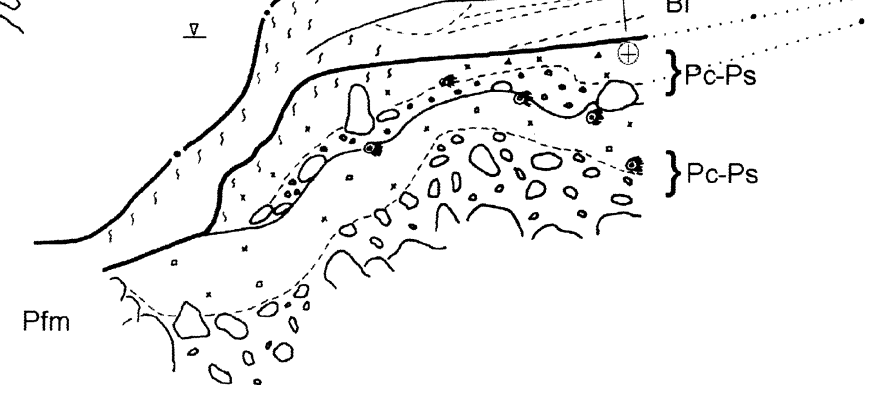


(h) Exit Pool

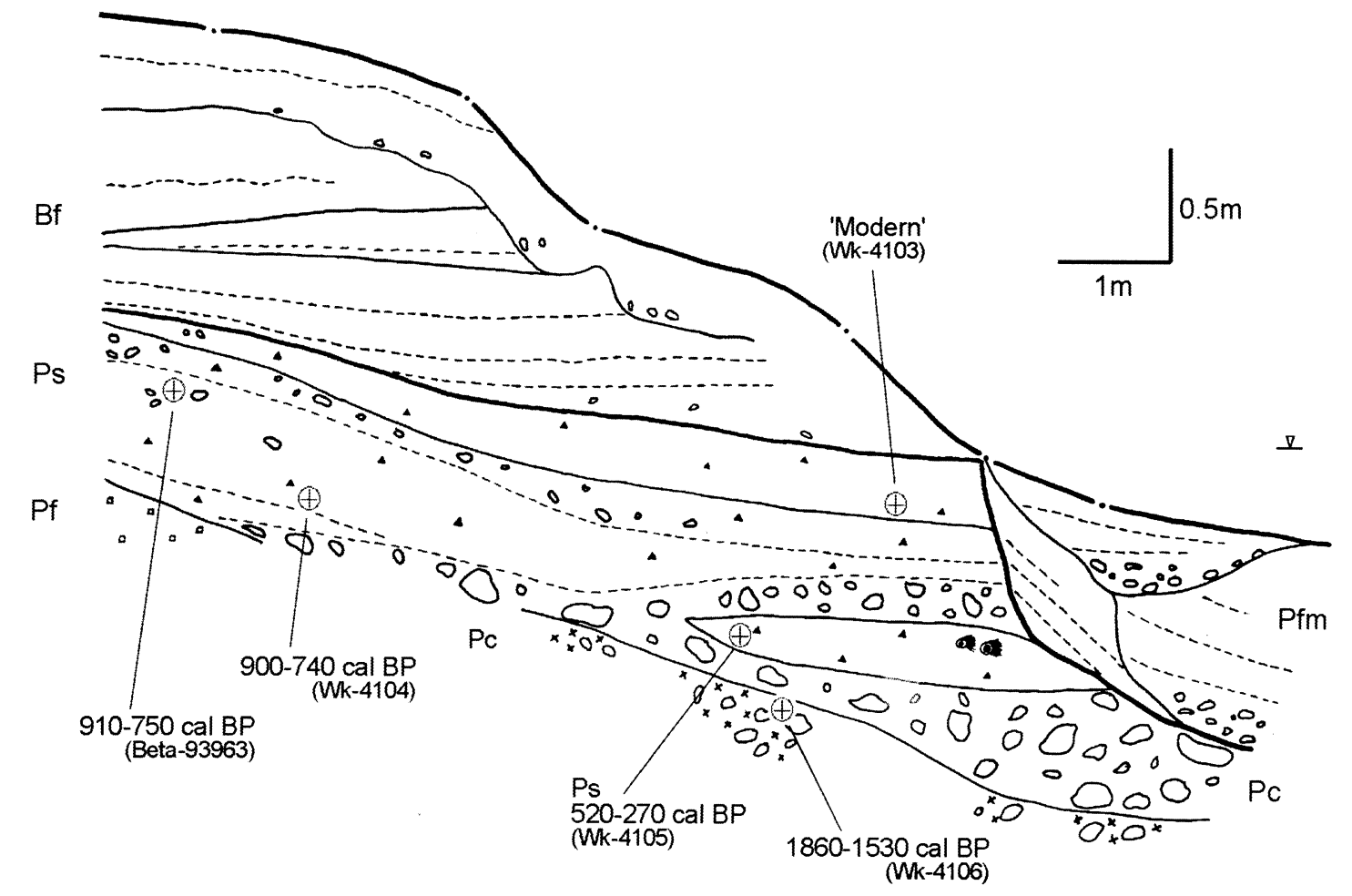

Fig. 7. (Continued).

sedimentary structures (resulting from intense bioturbation and/or weathering). This type of unit is associated with the waning stages of large floods in which bedload sheets constitute bar supraplatforms that grade up from underlying coarse-grained bar platforms (Fig. 8). Successive major floods episodically scour and replace the supraplatform deposits. These units generally have lenticular to tabular geometry, reflecting the movement of bedload in sheets, and they tend to thicken channelwards; however, the original geometry is rarely preserved owing to scour. As these units extend beneath the benches, their preservation records the intervals between floods that are sufficiently powerful to destroy the benches.

\section{Fine-grained pool-fill $\left(P_{f}\right)$}

These chiefly fine-grained deposits (typically $>60 \%$ mud and $<<1 \%$ gravel) are usually greyish-brown, poorly sorted and massive or have faint primary sedimentary structures (resulting from intense bioturbation and/or weathering). This unit indicates low-energy depositional environments in which fine sediments were deposited on vegetated pool floors under low flows
(Fig. 9). The geometry is concave-up, lenticular or oblique and tends to thicken channelwards. The moisture-holding capacity of this unit has fostered germination of river red gums with extensive root networks that reinforce the sediments. Fine-grained bench deposits $\left(\mathrm{B}_{\mathrm{f}}\right)$ generally overlie this unit.

Fine-grained bench $\left(B_{f}\right)$

These fine-grained top-stratum deposits (typically $>50 \%$ mud with gravel absent) comprise a series of reddish-brown, thinly interbedded, upward-fining flood cycles reflecting deposition during rising and waning stage. Signs of light bioturbation, such as root-channel infills and macro-invertebrate burrows, are present. Each flood cycle is often deposited on to an eroded base and generally grades from laminated coarse sands up to a muddy drape (Fig. 10). This unit indicates a low- to moderate-energy depositional environment, with recirculating eddies favouring sedimentation during large floods (Fig. 5). The geometry is sigmoidal and draping, convex-up or oblique, thinning channelwards. This unit extends above the level of maximum ponding in the pools (as governed by the riffle crest downstream) 


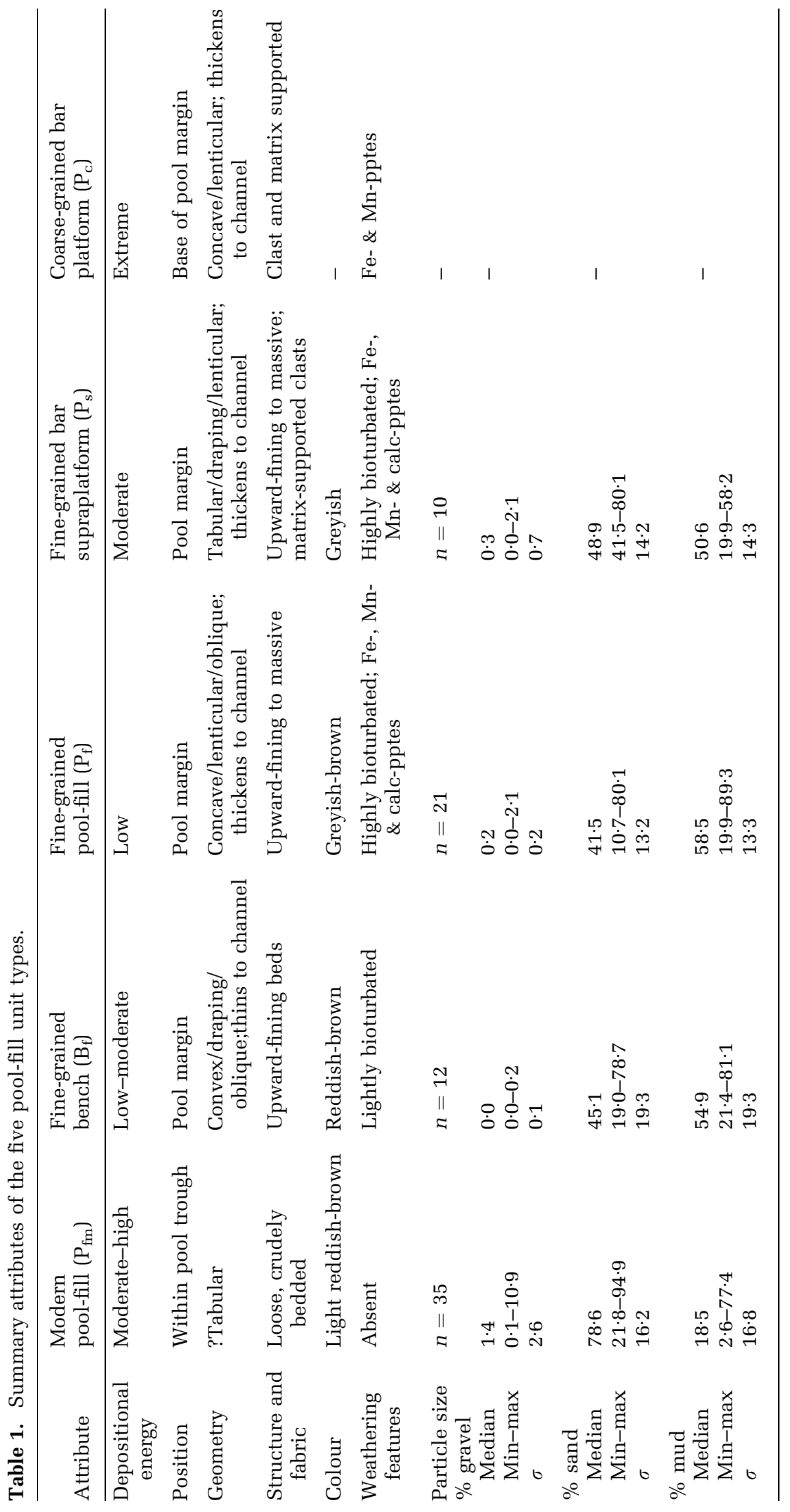




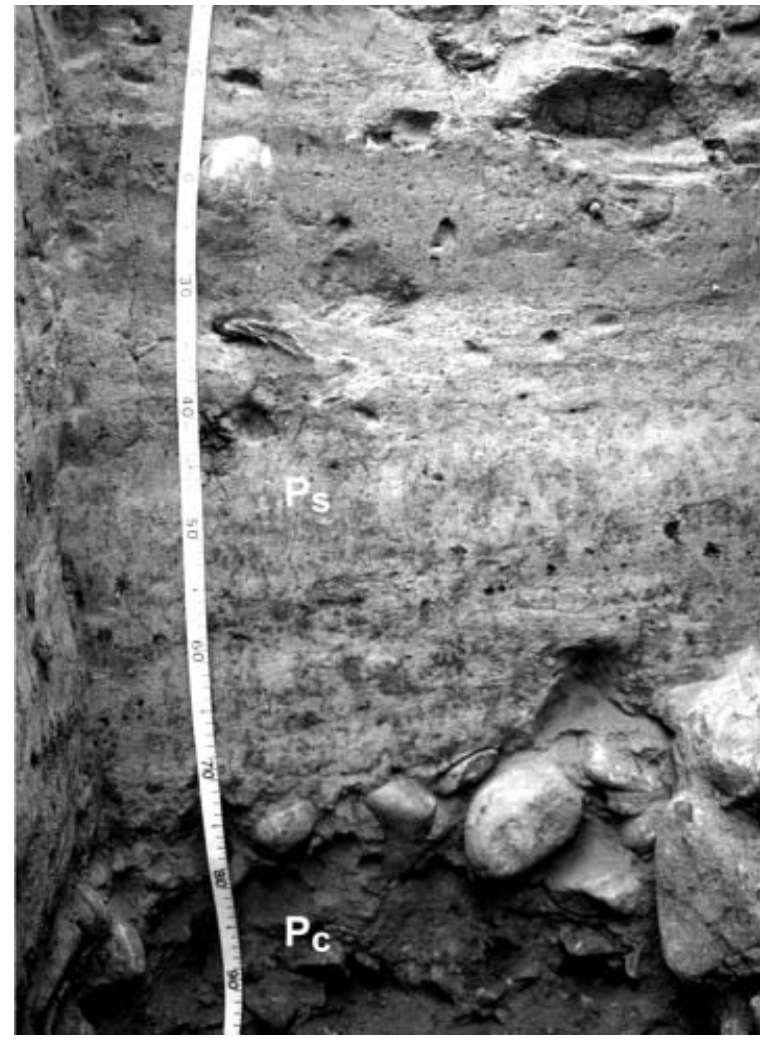

Fig. 8. Coarse-grained bar platform $\left(\mathrm{P}_{\mathrm{C}}\right)$ topped by finegrained supraplatform deposits $\left(\mathrm{P}_{\mathrm{s}}\right)$ at Exit Pool (denoted by grey patch in Fig. 7h; flow from left to right). Note the occasional floating gravels and cohesive nature of the $\mathrm{P}_{\mathrm{s}}$.

and usually caps an assemblage of units in the form of a bench. Accretion and preservation are enhanced by growth of chenopods and ephemeral

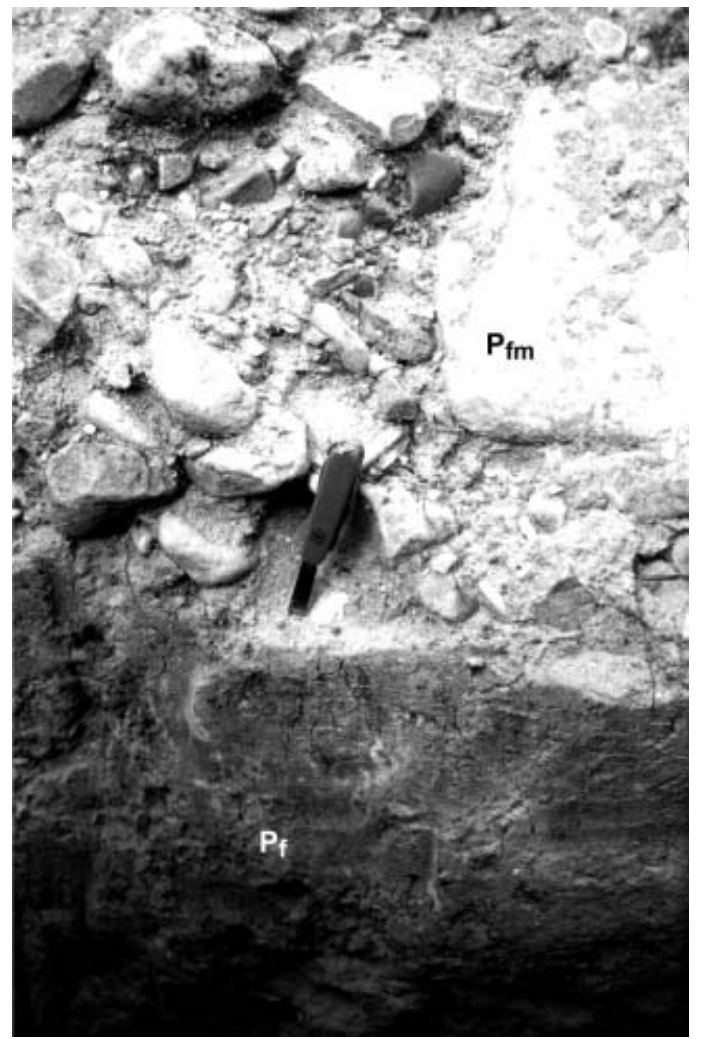

Fig. 9. Modern pool-fill $\left(\mathrm{P}_{\mathrm{fm}}\right)$ associated with a large flood in 1992, which eroded the underlying finegrained pool-fill $\left(\mathrm{P}_{\mathrm{f}}\right)$ at Rockart Pool (denoted by grey patch in Fig. 7c; downstream view).

herbage on the bench surface. Riparian river red gums commonly stand with their bases buried up to $1 \mathrm{~m}$ in these materials.

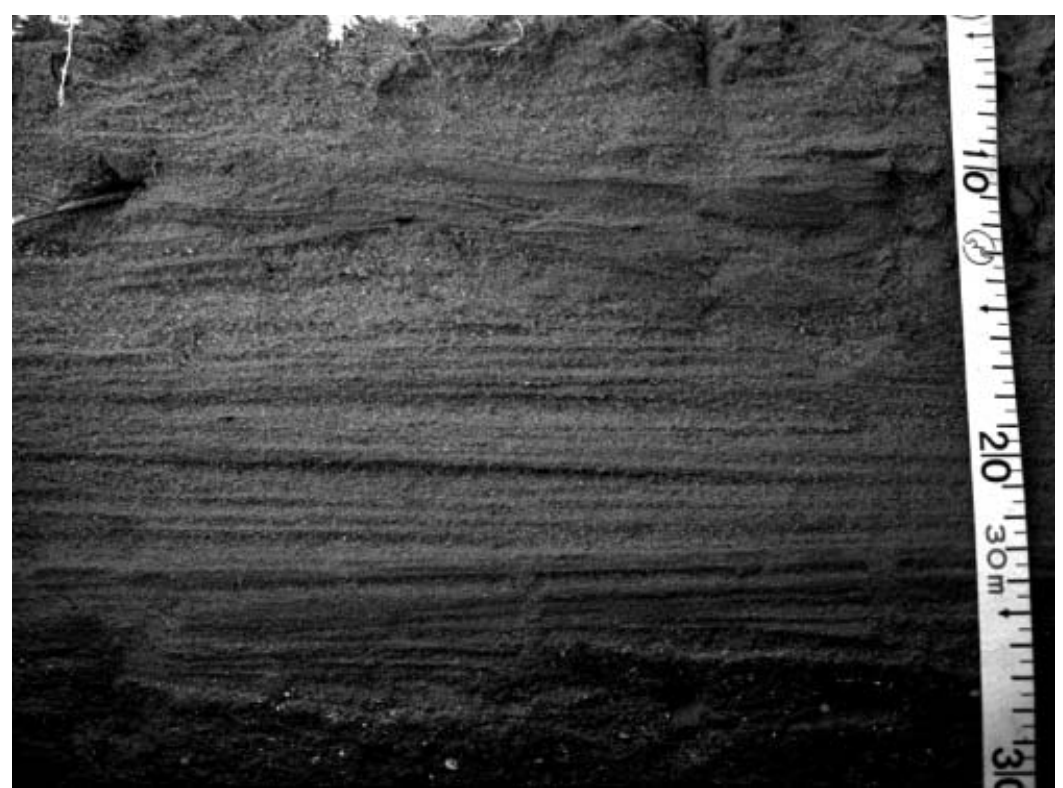

Fig. 10. Fine-grained bench $\left(\mathrm{B}_{\mathrm{f}}\right)$ flood cycles fine upwards from coarse basal sand to subhorizontal sand-mud laminae to thin mud drapes, with some cross-lamination; Exit Pool (denoted by grey patch in Fig. 7h; flow from left to right). 
Modern pool-fill $\left(P_{f m}\right)$

This mixture of coarse- and fine-grained sediments (typically $<20 \%$ mud and $>1 \%$ gravel) is very poorly sorted, loose and crudely bedded and free of in situ weathering or alteration (Fig. 9). This unit indicates rapid deposition under moderate- to high-energy conditions; the materials are frequently reworked and remain on the pool floor only until the next major flood.

\section{Textural attributes}

Graphical results of particle-size analyses indicate that respective proportions of gravel and mud provide a reasonable discriminator of $\mathrm{P}_{\mathrm{fm}}$, $\mathrm{P}_{\mathrm{s}}, \quad \mathrm{P}_{\mathrm{f}}$ and $\mathrm{B}_{\mathrm{f}}$ units, although considerable overlap exists (Fig. 11). The modern pool-fill is considerably more gravelly and less muddy than the older deposits. $\mathrm{P}_{\mathrm{f}}$ and $\mathrm{B}_{\mathrm{f}}$ sediments contain similar proportions of mud; however, $\mathrm{B}_{\mathrm{f}}$ rarely features gravel (all contain $\leq 0 \cdot 2 \%$ gravel), and $\mathrm{P}_{\mathrm{f}}$ gravel content is more variable and often ranges close to $1 \%$. The proportion of mud in $\mathrm{P}_{\mathrm{s}}$ occupies the overlap between the $\mathrm{P}_{\mathrm{fm}}$ and $\mathrm{P}_{\mathrm{f}}$ domains, consistent with the interpretation of $\mathrm{P}_{\mathrm{s}}$ as bedload sand-sheets deposited during waning stages.

\section{OVERVIEW OF THE POOL-FILL ASSEMBLAGES}

\section{Unit position and morphology}

The sedimentary unit assemblages can be generalized in terms of their geometry, preservation and stacking arrangement (Fig. 12a). Coarsegrained $\mathrm{P}_{\mathrm{C}}$ units line the base of the pool troughs and form the foundation for the fine-grained $\mathrm{P}_{\mathrm{s}}$ units. $\mathrm{P}_{\mathrm{C}}$ and $\mathrm{P}_{\mathrm{s}}$ units exhibit tabular morphology

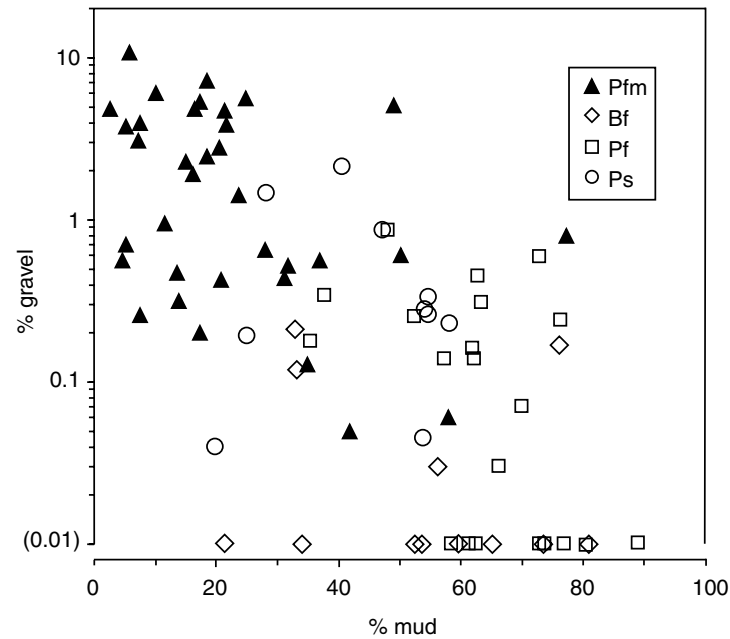

Fig. 11. Textural relationships among sedimentary units. Discrimination between $\mathrm{P}_{\mathrm{fm}}, \mathrm{B}_{\mathrm{f}}, \mathrm{P}_{\mathrm{f}}$ and $\mathrm{P}_{\mathrm{s}}$ units based on percentage gravel $(>2 \mathrm{~mm})$ relative to percentage mud $(<63 \mu \mathrm{m})$. Note that samples lacking gravel are ascribed with a nominal $0.01 \%$ gravel. Muddier $\mathrm{P}_{\mathrm{fm}}$ outliers denote samples from localized patches where suspended muds settle out as the pools dry up completely.

before reworking. Remnants of two stacked $\mathrm{P}_{\mathrm{c}}-\mathrm{P}_{\mathrm{s}}$ couplets occur in each pool. The original unit morphology is almost intact in Belah Pool but, more generally, the upper part of the $\mathrm{P}_{\mathrm{s}}$ is truncated, and the irregular erosion surface records broad channel morphology (e.g. Strait, Stumpy and Exit Pools). In Murder Pool and Rockart Pool, the $\mathrm{P}_{\mathrm{s}}$ units are removed altogether, and the eroded remnant of the basal couplet is difficult to distinguish.

Mud-rich $\mathrm{P}_{\mathrm{f}}$ units present a lenticular morphology that thickens channelwards, draping $\mathrm{P}_{\mathrm{c}}-\mathrm{P}_{\mathrm{s}}$ couplets (where preserved) up to the level of maximum ponding. Erosion of $\mathrm{P}_{\mathrm{f}}$ units generally occurs as lateral truncation at the contemporary

(a)

Fig. 12. Schematic pool-fill unit position and morphology: (a) generalized sequence of pool-fill units before and after major flood erosion; (b) flat assemblage; (c) asymmetric inclined assemblage; and (d) symmetric inclined assemblage.

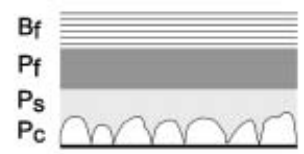

(b)

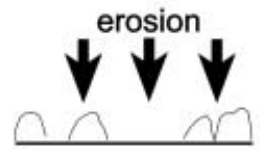

post-flood

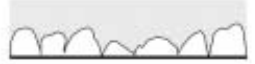

(c)

(d)

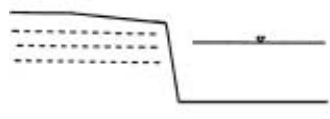

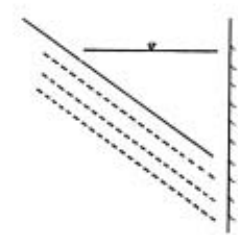

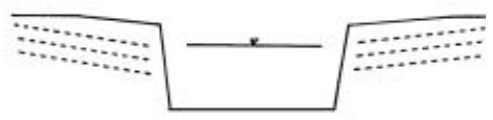


bank. The upper erosion surface of the $\mathrm{P}_{\mathrm{f}}$ may be near-planar (e.g. Belah and Stumpy Pools) or trough-shaped (e.g. Murder, Rockart and Strait Pools).

$\mathrm{B}_{\mathrm{f}}$ units accrete on to erosion surfaces cut across $P_{f}$ units and hence post-date the major entrenchment phase that defines the current pool morphology. Minor internal erosion surfaces fail to modify the original draping habit of the $\mathrm{B}_{\mathrm{f}}$ units. These sediments thickly blanket the underlying stack of in-channel $\mathrm{P}_{\mathrm{c}}, \mathrm{P}_{\mathrm{s}}$ and $\mathrm{P}_{\mathrm{f}}$ units. Benches located close to flow separation points clearly reflect recirculating eddy flow, with the inner bank delineating the shear surface (eddy line) that separates the eddy from the mainstream (Fig. 5).

$\mathrm{P}_{\mathrm{fm}}$ units line the pool floors typically to a depth of $1 \mathrm{~m}$ or so; these lie entrenched within the older in-channel units that now constitute the cohesive banks of the contemporary pools. Their morphology and internal structure were examined in detail in Rockart and Exit Pools only: a nested series of lenticular cut-and-fills suggests frequent reworking.

\section{Pool-fill assemblage types}

Three pool-fill assemblage types are recognized and represented schematically in Figure 12: a flat assemblage (e.g. Belah Pool; Fig. 12b); an asymmetric inclined assemblage (e.g. Rockart and Exit Pools; Fig. 12c); and a symmetric inclined assemblage (e.g. Murder, Strait, and Stumpy Pools; Fig. 12d). Each pool-fill is shaped by local patterns of flow convergence, hydraulic jetting and recirculating eddies, with assemblage types reflecting their location relative to flow constrictions caused by rock outcrops, tributary fans, terraces or coarse-grained floodplains.

A steep tributary fan causes mild constriction at Belah Pool. The flat and sheet-like morphology of depositional units combined with planar erosion surfaces reflects the less confined setting and shallower flows of the upper reaches of Sandy Creek gorge (Figs $12 \mathrm{~b}$ and 13). In contrast, the channel zone is cut in bedrock at the two most confined sites, Exit Pool and Rockart Pool, and a large increase in floodstage accompanies rising discharge. The Exit Pool and Rockart Pool exposures reveal the internal architecture of the poolfill bench and beneath the pool floor. Here, the pool-fill assemblages reflect the passage of deep, convergent, high-energy flows at bedrock bends that deflect the thalweg $60-90^{\circ}$ (Figs 4, 5 and 12c). Roughly parallel, inclined erosion surfaces at Rockart Pool and Exit Pool indicate that this distinctive pattern is probably linked to vortices generated at the bedrock bend. These vortices maintain a scour hole at the base of the bedrock bend in both these pools. Intermediate between these two confinement extremes, flow constriction imposed by terraces at Murder Pool and Stumpy Pool and a coarse-grained floodplain at Strait Pool produce symmetrical, but not necessarily paired, inclined pool-fill assemblages (Figs 6 and 12d). This type reflects scour by large flows; however, once flow stage exceeds the level

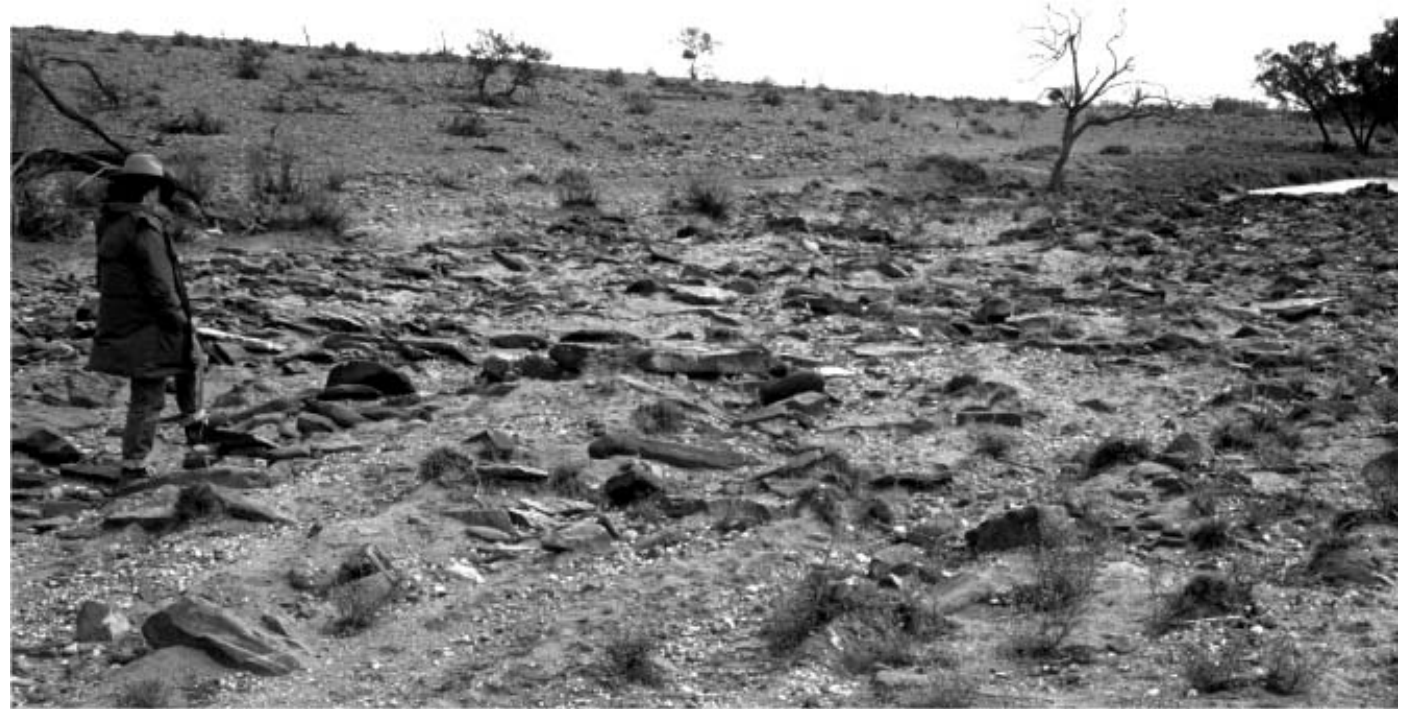

Fig. 13. The relatively unconfined valley at Belah Riffle looking upstream to the pool-fill bench, which forms the right bank of Belah Pool at top right. Note the relatively fine sediments draping imbricated, coarse riffle boulders. 
of the constriction (the terrace or floodplain), the flow expands and stream power dissipates. Consequently, these pool-fills have higher preservation potential and favour longer storage terms compared with pool-fills at Rockart and Exit Pools.

Consistent patterns in the morphology, stacking order and preservation of the sedimentary units indicate a recurrent pattern of pool infilling and reworking. This suggests that the pool-fills provide insights into the alluvial record extending back to the most recent superflood that flushed out and eroded the pool-fills back to bedrock.

\section{LATE HOLOCENE PALAEOFLOOD HISTORY}

\section{Results and analysis of the radiocarbon dates}

Several buried hearths (ovens) built by indigenous people were encountered in the pool-fill excavations; many containing charred woody material suitable for radiocarbon dating. Dated hearths are particularly useful in fluvial sequences. As they are typically intrusive structures excavated into the ground surface of the time, the charred matter can be assumed to have burnt in situ, thereby curbing dating errors due to fluvial reworking (Blong \& Gillespie, 1972; Baker, 1989). Dating yields a minimum-limiting age estimate of the host sedimentary unit and a maximum-limiting estimate for the overlying unit.

A summary of the 13 radiocarbon dates is given in Table 2. Calibrated ages (cal BP) are represented by the upper and lower bounds of one standard deviation (Stuiver \& Reimer, 1993; Stuiver et al., 1998). Only one anomalous result was returned: at Exit Pool (Fig. 7h) the 520-270 cal BP (Wk-4105) age is difficult to reconcile with the overlying unit, which is securely dated from two separate hearths at 900-740 cal BP (Wk-4104) and 910-750 cal BP (Beta-93963). Contamination with young carbon is the most likely explanation.

An Aboriginal hearth dated at 480-340 cal BP (Wk-4197) was located within a tributary-mouth slackwater deposit formed by the backing up of floodwaters at the Exit Pool constriction $30 \mathrm{~m}$ downstream (Fig. 4). However, the deposit might equally be described as a concave-bank bench (Page \& Nanson, 1982); it comprises $40 \mathrm{~cm}$ of subhorizontal, wavy, laminated, fine red sands overlying $40 \mathrm{~cm}$ of massive, very fine to fine brownish sands with abundant charcoal fragments and fire-cracked stones in a lenticular hearth structure. A maximum-age estimate of roughly 800 years for the whole deposit is gained by extrapolating a constant sedimentation rate down from the upper boundary of the dated charcoal layer, assumed to be European contact $c$. $\mathrm{AD}$ 1860s. This age is consistent with three other hearth ages: two from Exit Pool (Fig. 7h), 910-750 cal BP (Beta-93963) and 900-740 cal BP (Wk4104); and one, 960-800 cal BP (Wk-4102), from a hearth that is highly vulnerable to flood erosion along a tributary creek (its position is shown in Fig. 2c).

In contrast, three other highly denuded hearths near Sandstone Tank (Fig. 2b), upstream of the gorge, yield much older ages: 2330-2120 cal BP (Beta-4865), 3640-3350 cal BP (Beta-4867) and 3870-3370 cal BP (Beta-4866) (Fanning, 1984). The presence of these older hearths preserved outside the gorge supports the notion that alluvium and associated artefacts are episodically flushed out of the gorge by rare large floods. Five dates from $\mathrm{P}_{\mathrm{f}}$ and $\mathrm{P}_{\mathrm{s}}$ deposits (OZD281, OZD-282, OZB-915, OZB-916, OZC-370) indicate pool-infilling over the period $570-260$ cal BP (Fig. 7).

\section{Relative dating using river red gums}

Table 3 presents a summary of data from excavations around 10 river red gums of widely differing size growing from pool-fill benches. Some trees stand with their basal root-flares (marking germination level) buried more than $1 \mathrm{~m}$ in sediment, thereby indicating shifts in sedimentation patterns over their life spans, which is estimated at 'not much over 400 years' (Ogden, 1978, p. $344)$.

The elevation of maximum ponding in each pool reflects the height of their respective downstream riffle crests and, given the presence of coarse boulders $\left(d_{95}=1070 \mathrm{~mm}\right)$, exceptionally large floods are necessary to effect change. Table 3 reveals two groups: small trees $(\leq 64 \mathrm{~cm})$, which germinated from a level associated with current riffle-crest elevations; and larger, presumably older trees $(\geq 71 \mathrm{~cm})$, which germinated from considerably deeper in the alluvial sequence. As the smaller trees $(\leq 64 \mathrm{~cm})$ span a remarkably narrow envelope of just a few centimetres in vertical extent, these data suggest indirect evidence of abrupt riffle-crest aggradation occurring over the life span of extant river red gums. 


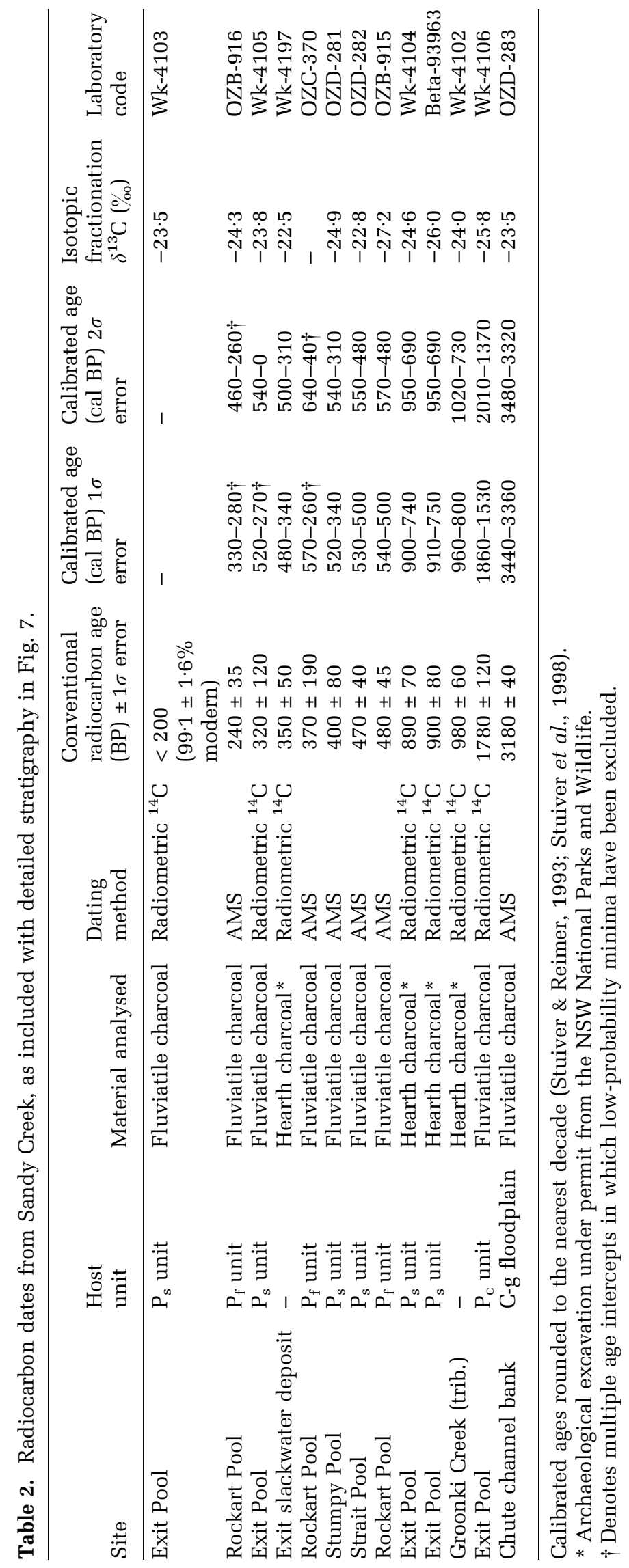


Table 3. Summary attributes of selected river red gums growing from pool-fill benches (corresponding to detailed stratigraphy in Fig. 8).

\begin{tabular}{lllll}
\hline Pool & $\begin{array}{l}\text { d.b.h.* } \\
(\mathrm{cm})\end{array}$ & $\begin{array}{l}\text { Burial depth } \\
(\mathrm{cm})\end{array}$ & $\begin{array}{l}\text { Relative elevation of } \\
\text { germination }\end{array}$ & $\begin{array}{l}\text { Germination host } \\
\text { sedimentary unit }\end{array}$ \\
\hline Stumpy Pool (lb) & 16 & 30 & $\approx$ Max. ponding & Upper boundary of $\mathrm{P}_{\mathrm{f}}$ \\
Strait Pool (lb) & 24 & 80 & $\approx$ Max. ponding & Upper $\mathrm{P}_{\mathrm{c}}$ \\
Strait Pool (in-stream) & Mallee & Scoured & $\approx$ Max. ponding \\
Stumpy Pool (rb) & 46 & $>105$ & $\approx$ Max. ponding & Lower $\mathrm{P}_{\mathrm{c}}-\mathrm{P}_{\mathrm{s}}$ couplet \\
Stumpy Pool (head) & 49 & Scoured & $\approx$ Max. ponding & $\mathrm{P}_{\mathrm{c}}-\mathrm{P}_{\mathrm{s}}$ couplet? \\
Strait Pool (in-stream) & 64 & Scoured & $\approx$ Max. ponding & Lower $\mathrm{P}_{\mathrm{c}}-\mathrm{P}_{\mathrm{s}}$ couplet \\
Rockart Pool (rb) & 71 & $>100$ & $>42 \mathrm{~cm}$ below max. ponding & Lower $\mathrm{P}_{\mathrm{c}}-\mathrm{P}_{\mathrm{s}}$ couplet \\
Murder Pool & $\sim 80 \dagger$ & 20 & $32 \mathrm{~cm}$ below max. ponding & $\mathrm{Bas}_{\mathrm{c}}$ ? \\
Exit Pool (rb) & 84 & $>80$ & $>40 \mathrm{~cm}$ below max. ponding & $\mathrm{P}_{\mathrm{c}}-\mathrm{P}_{\mathrm{s}}$ couplet? \\
Stumpy Pool (lb) & $155 \dagger$ & 85 & $50 \mathrm{~cm}$ below max. ponding & $\mathrm{P}_{\mathrm{c}}-\mathrm{P}_{\mathrm{s}}$ couplet? \\
\hline
\end{tabular}

*Tree diameters refer to diameter at breast height (d.b.h.).

$\dagger$ Denotes eroded stumps.

Fig. 14. Calibrated radiocarbon dates (cal BP) with error bars representing $\pm 1 \sigma$ and $\pm 2 \sigma$. Shaded areas denote periods of erosion not recorded by pool-fill sedimentation.

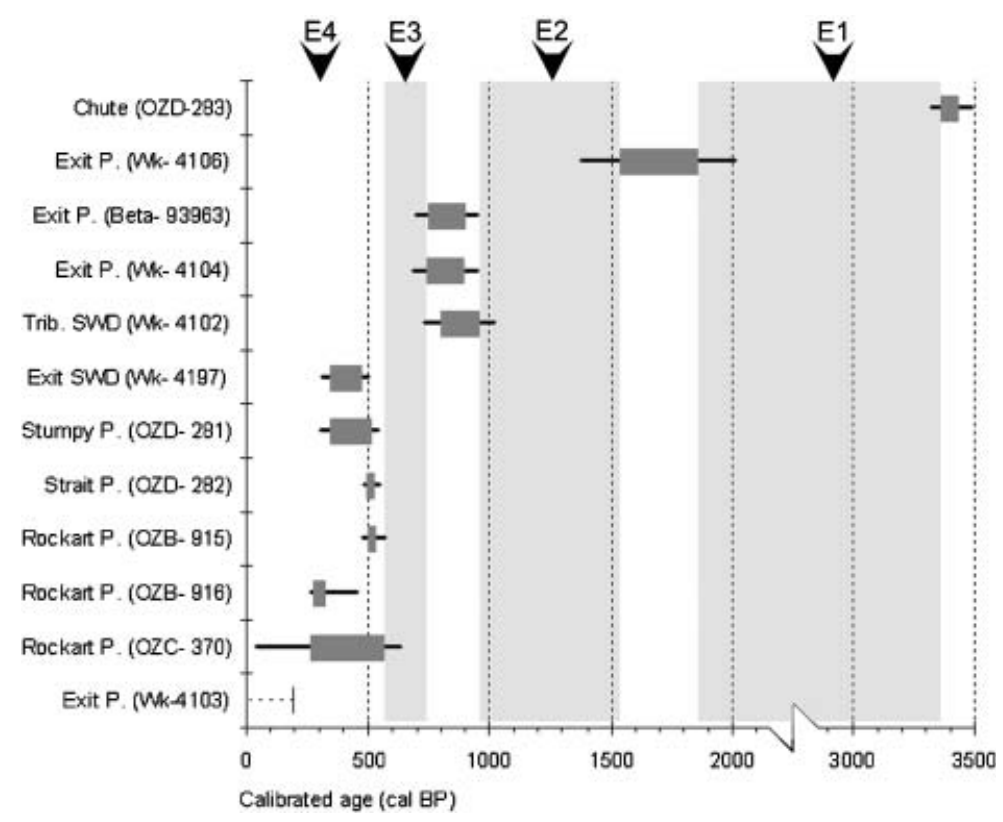

\section{Overview of erosional and depositional episodes}

The characteristically flashy nature of flows in this arid zone ephemeral stream results in a combination of rapid deposition and abrupt erosional episodes. At least two phases of erosion are identified in the pool-fills. Briefly following scour, large floods deposit bar platforms $\left(\mathrm{P}_{\mathrm{C}}\right)$ grading up to supraplatform deposits $\left(\mathrm{P}_{\mathrm{s}}\right)$ in waning stages (Fig. 12a). Two such episodes are apparent (i.e. two stacked sets of $\mathrm{P}_{\mathrm{C}}-\mathrm{P}_{\mathrm{s}}$ couplets). Both were associated with the scouring of a broad channel-way, and low-energy
$\mathrm{P}_{\mathrm{f}}$ deposits drape the eroded couplets (indicated by their erosional upper boundary). A subsequent flood then incised the sequence and scoured a deep pool trough. It is not clear why this flood cut vertically rather than laterally across the pool, but river red gums possibly supplied additional reinforcement. Accretion on the shallow pool margins has since formed thick draping benches along the major pools. No major pool scour has occurred over the recent past possibly not since European settlement. The timing of erosion or deposition episodes is constrained approximately using the one standard deviation ranges of the calibrated ages in 
Table 4. Major erosional and depositional episodes in Sandy Creek gorge over the late Holocene.

\begin{tabular}{|c|c|c|}
\hline $\begin{array}{l}\text { Erosional/depositional } \\
\text { episode }\end{array}$ & Magnitude & $\begin{array}{l}\text { Estimated } \\
\text { age (cal BP) }\end{array}$ \\
\hline Erosion episode 1 & Extreme & $3360-1860$ \\
\hline Erosion episode 2 & High & 1530-960 \\
\hline Erosion episode 3 & Moderate & $740-570$ \\
\hline Erosion episode 4 & Moderate & $\approx 300$ \\
\hline $\mathrm{P}_{\mathrm{f}}$ deposition & Low & $570-260$ \\
\hline $\begin{array}{l}\text { Post-settlement } \\
\text { regime }\end{array}$ & Low-moderate & post-AD 1860s \\
\hline
\end{tabular}

Fig. 14, and these are summarized in Table 4. Evolution of the Sandy Creek pools over the late Holocene is represented schematically in Fig. 15.

\section{Erosion episode 1 (E1)}

The pool-fills post-date the most recent superflood designated here as E1. The Exit Pool basal age of 1860-1530 cal BP (Wk-4106) provides a key minimum-age constraint on the superflood, as it is located at one of the most pronounced gorge constrictions. The coarse basal sediments $\left(\mathrm{P}_{\mathrm{c}}-\mathrm{P}_{\mathrm{s}}\right)$ are possibly waning-stage deposits or sediments linked to subsequent smaller floods. Corresponding basal materials of a similar weathered nature also occur in Belah, Murder and Stumpy Pools.

While superfloods certainly caused broad-scale erosion, they are unlikely to have flushed gorges completely because of the variable downstream stream power distribution. Pre-superflood sediments are likely to persist in valley expansions, such as that upstream of Exit Pool where basal gravels exposed in the bank of a large chute channel (Fig. 16) are dated at 3440-3360 cal BP (OZD-283). These gravels are interpreted as the eroded remnant of an old floodplain, and so provide a maximum age for the E1 superflood.

\section{Erosion episode 2 (E2)}

Broad pool-troughs were eroded to roughly double the width of the present channel. Strait Pool and the Rockart Pool floor were returned to bedrock, and weathered basal $\mathrm{P}_{\mathrm{C}}-\mathrm{P}_{\mathrm{s}}$ couplets (or remnants of these) were truncated in Belah, Murder, Stumpy and Exit Pools. The upper $\mathrm{P}_{\mathrm{c}}-\mathrm{P}_{\mathrm{s}}$ couplets in Belah, Stumpy and Exit Pools and Murder Pool (upper $\mathrm{P}_{\mathrm{c}}$ unit only) possibly represent waning-stage deposits. E2 timing is bracketed by the Exit Pool basal age, 1860-1530 cal BP (Wk-4106) and three hearth ages: 910-750 cal BP
Fig. 15. Generalized time slices of pool morphology and stratigraphy over the late Holocene. A late Holocene superflood eroded the pool-fills back to bedrock and remnant coarse lag. Repeated cut-and-fill episodes associated with subsequent smaller magnitude floods yielded net aggradation. Post-settlement increased sediment supply has caused narrowing and filling of the pool troughs.

(Beta-93963), 900-740 cal BP (Wk-4104) and 960800 cal BP (Wk-4102). The slackwater deposit near Exit Pool was probably also removed at this time.

Erosion episode 3 (E3)

E3 was less geomorphically effective than either E1 or E2. Moreover, the larger flood that followed (E4) probably overprinted many of the erosion surfaces. Some incision of pool-troughs probably occurred, but there was insufficient power to strip the pool-fills laterally. Rockart Pool was very likely scoured to bedrock, as was Strait Pool along the thalweg.

\section{Erosion episode 4 (E4)}

E4 probably established the current pool morphology and may have interrupted widespread $P_{f}$ deposition. Evidence is clearest in the erosion surfaces cut across upper $\mathrm{P}_{\mathrm{c}}-\mathrm{P}_{\mathrm{s}}$ couplets over which the $\mathrm{P}_{\mathrm{f}}$ units were deposited. Pools were also widened, although less than with E2, and pool incision was predominant in Stumpy, Rockart and Strait Pools - the last two were scoured to bedrock along the thalweg. Evidence for scouring through the chute channel is manifest in the Strait Pool right-bank where the upper $\mathrm{P}_{\mathrm{C}}$ unit is completely removed. Flood scars on senescent gums at Rockart Pool indicate the peak floodstage of an exceptional flood around 300 cal BP. Riffle-crest elevations have probably remained stable since that time.

\section{$P_{f}$ deposition}

The onset of prolonged deposition is indicated shortly before 500 cal BP. This period is characterized by low-energy $\mathrm{P}_{\mathrm{f}}$ deposits on well-vegetated pool floors and drapes over eroded $\mathrm{P}_{\mathrm{C}}-\mathrm{P}_{\mathrm{s}}$ couplets at pool margins. Rockart Pool contains particularly thick $\mathrm{P}_{\mathrm{f}}$ units dated by three allochthonous charcoal ages spanning 570-260 cal BP. While $\mathrm{P}_{\mathrm{f}}$ deposition was probably interrupted by $\mathrm{E} 4$ (c. $300 \mathrm{cal} \mathrm{BP}$ ), preservation of these fills beneath the Rockart pool-floor suggests a lack of subsequent major floods. 
(a) c. $3360-1860 \mathrm{cal} \mathrm{BP}$, after the superflood, E1.

(b) c. $800 \mathrm{cal} \mathrm{BP}$,

between erosion episodes, E2 and E3.

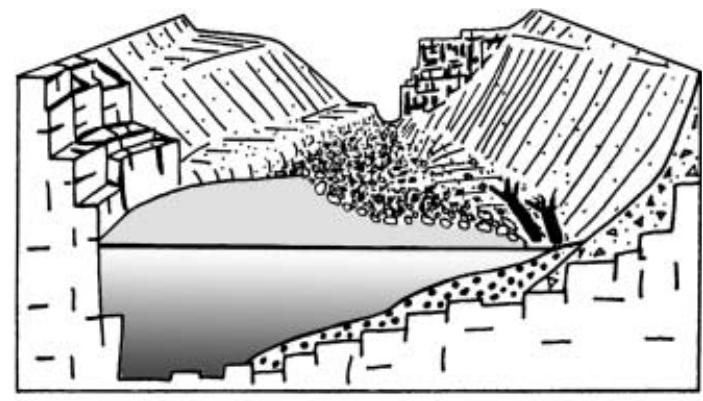

(c) c. $\mathrm{AD} 1650$ (300 cal BP), after erosion episode, E4.
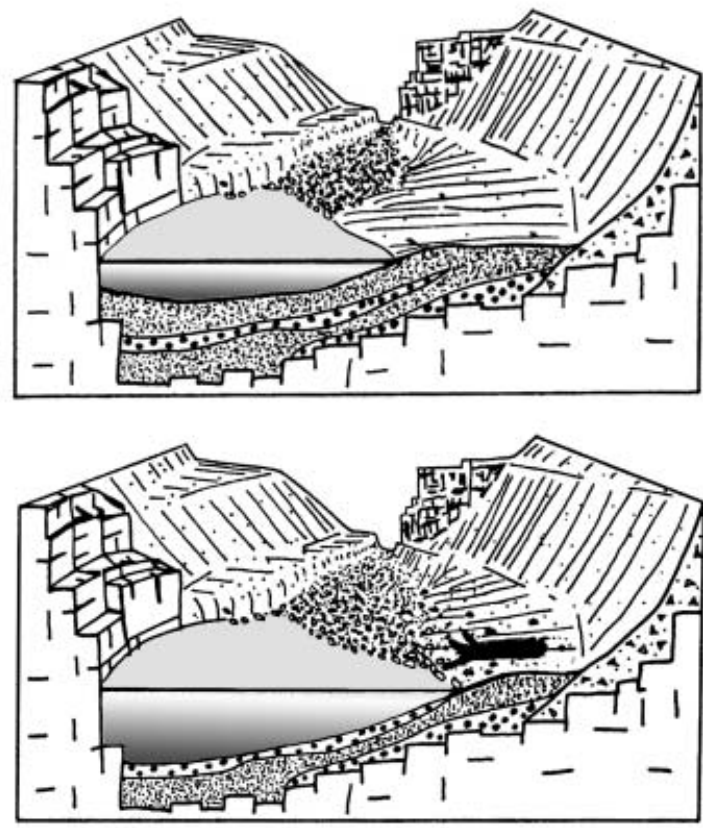

(d) c. $\mathrm{AD} 1850$,

prior to European settlement.

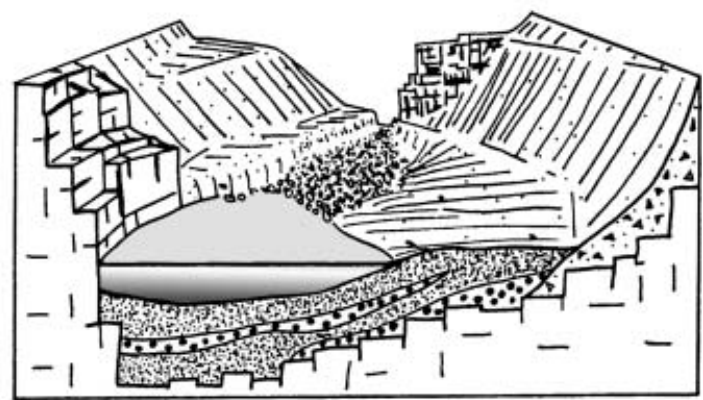

(e) c. $\mathrm{AD} 2000$,

the contemporary pool.
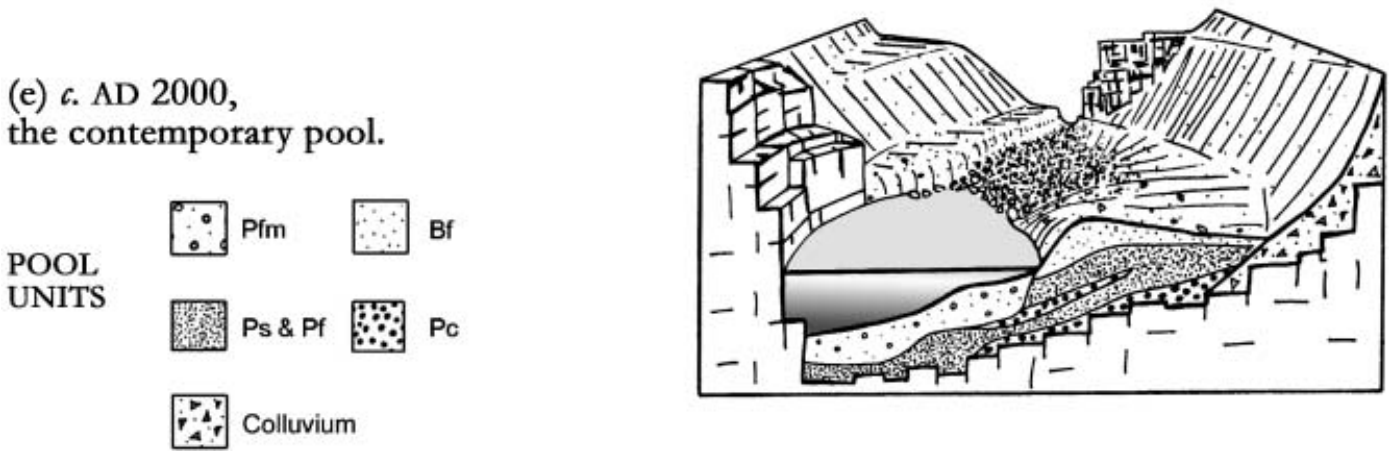


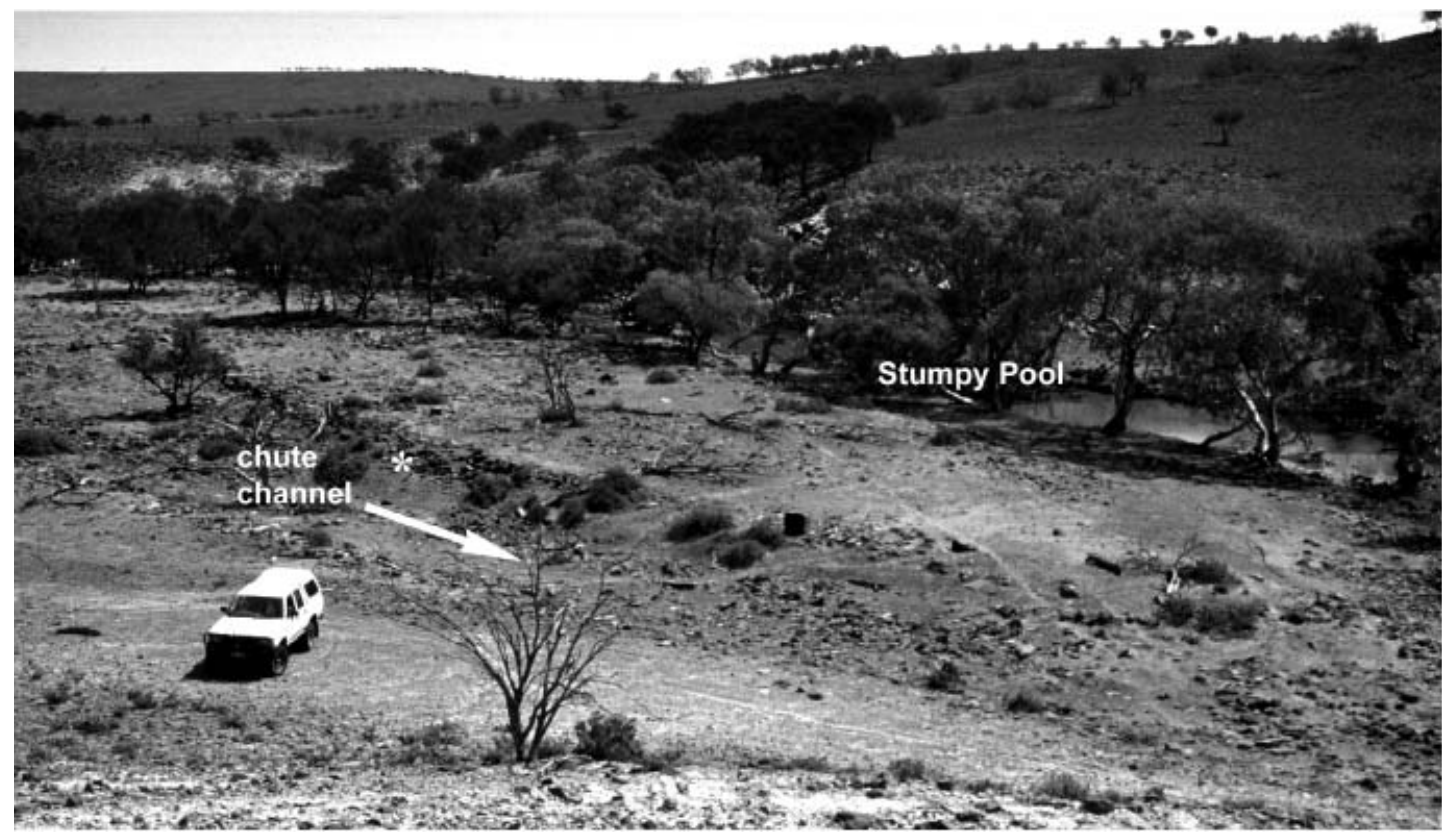

Fig. 16. Chute channel and Stumpy Pool, looking upstream (Fig. 4). The asterisk denotes the position of the radiocarbon sample OZD-283 (Table 2).

\section{Post-settlement regime: bench accretion} and the modern pool-fill

Abundant overbank deposits have partly refilled the chute channel (Fig. 16), and pool width has diminished with the accretion of bench drapes 1-2 $\mathrm{m}$ in thickness. Some minor erosion has occurred over this period: Strait (left-bank), Stumpy and Belah Pools all contain erosion surfaces in the basal portion of their $B_{f}$ units; $B_{f}$ deposits in Exit Pool contain three internal erosion surfaces, at least one of these extending into the present pool-trough; and internal erosion surfaces occur in the Rockart Pool modern fill.

According to photographic evidence and preand post-flood field assessments, the passage of a $170 \mathrm{~m}^{3} \mathrm{~s}^{-1}$ flood in 1992 (a 100-year event) exerted very limited changes to the channel zone (Jansen, 2001); shallow scour and fill was recorded in Rockart Pool (Figs 7c and 9), and a few centimetres of sediment were skimmed off the bench tops. As no evidence of sandy benches exists in the presettlement stratigraphy, it is inferred that $\mathrm{B}_{\mathrm{f}}$ and $\mathrm{P}_{\mathrm{fm}}$ units mark a shift in sedimentation style probably stemming from a decline in vegetation cover and increased sediment supply over the post-settlement period. Certainly, the low-energy environment and aquatic vegetation, which probably lined the muddy pool floors associated with the $\mathrm{P}_{\mathrm{f}}$ unit, no longer exist.

\section{DISCUSSION}

\section{Comparing pool-fills with eddy bars and slackwater deposits}

Recirculating currents, or eddies, are ubiquitous along irregular, bedrock-cut channels, occurring wherever the orientation of downstream flow and the channel banks are sufficiently divergent (Schmidt et al., 1993). The eddy bars that result are widely noted in bedrock rivers (Baker et al., 1983; Baker, 1984); moreover, sediments stored in pool-fills and eddy deposits may comprise a large proportion of the total fine sediment storage in bedrock-confined rivers. Based on wellstudied examples in Grand Canyon, Schmidt (1986) subdivided eddy bars into separation deposits, reattachment deposits and eddy-centre deposits.

The fine-grained bench $\left(\mathrm{B}_{\mathrm{f}}\right)$ unit's high mud content (typically $>50 \%$ ) and positioning close to the flow separation point - the inner bank follows the shear surface separating eddy flow from the mainstream - is consistent with suspended-load deposition via eddies (Fig. 5). These convex-up deposits, which drape the underlying pool-fills, are probably akin to the separation bars found capping debris-fan deposits in Grand Canyon (Rubin et al., 1990; Schmidt, 1990). Schmidt \& Graf's (1990) observation that large Grand Canyon 
floods tended to erode reattachment bars more extensively than separation bars between 1965 and 1987 suggests that sedimentary units positioned close to the separation point might possess higher preservation potential. If so, this is consistent with the substantial storage terms represented by pool-fills underlying benches in Sandy Creek.

Flow constrictions commonly correspond to bedrock bends, particularly in strongly jointcontrolled valleys, and major pools in Sandy Creek all adjoin constricted bedrock bends that deflect the thalweg by $60-90^{\circ}$ (cf. O'Connor et al., 1986; Baker \& Pickup, 1987). A key aspect of the pool-fills involves the stage-dependent behaviour of flow through constrictions. During low flows, velocities through the pools remain low mainly because of the steep pool exit slopes (Fig. 4), whereas pools concentrate scour in large floods, acting as a series of high-energy nozzles (Figs 1a and 5). Post-scour preservation patterns among the pool-fill units underlying the benches (viz. $\mathrm{P}_{\mathrm{c}}$ $\mathrm{P}_{\mathrm{s}} \mathrm{P}_{\mathrm{f}}$ units) appear to reflect their positions relative to the erosive hydraulic jet generated through the pools (Kieffer, 1989; Thompson et al., 1999). Unlike the bench units, neither the geometry of the pool-fill units (viz. concave-up, lenticular or tabular and thickening channelwards) nor their extension below pool floors is compatible with deposition via eddies.

Stratigraphic sections of reattachment bars in Grand Canyon presented by Rubin et al. (1990) describe the uppermost 1-2 $\mathrm{m}$ of cross-bedded coarse sands deposited by dunes and bars since 1983. Typically a few metres thick in total, these supraplatform deposits are described as capping more resistant, eroded bar platforms at depth (Rubin et al., 1990). In bedrock rivers, eddy deposits might commonly rest on bar platforms that have formed under entirely different formative flows, as in Sandy Creek, where coarsegrained bar platforms do not reflect recirculation eddies, but rather an alternative high-energy process linked to the expanding hydraulic jet from the nearby constriction.

Although capped by fine-grained bench units linked to eddy flow, the pool-fill assemblages are principally forced-bars associated with forced riffle-pool morphology. It is suggested that basal gravels (the bedload component) within these forced-bars reflect processes analogous to the shock-waves involved with boulder berms formed at expansions in straight channels (Carling, 1987, 1989, 1995); however, this awaits further testing.
Unlike either pool-fills or eddy bars, palaeoflood slackwater deposits typically remain untouched by low- to moderate-magnitude flows; flume experiments show them to be essentially elevated eddy bars (Kochel \& Ritter, 1987; Kochel \& Baker, 1988). Slackwater deposits form during large floods via suspended-load deposition in backwater zones of stream power minima (Kochel \& Baker, 1988), quite the opposite to pool-fills, which occur close to sites of stream power maxima. The requisite channel and valley morphologies constrain the occurrence of useful slackwater deposits, and rivers with low suspended load tend not to deposit the thick accumulations that yield the most fruitful flood information. They are poorly developed in bedrock valleys of the Barrier Range. Whereas slackwater deposits accrete vertically and tend to preserve a self-censoring palaeoflood record (i.e. only successively larger floods add to the sedimentary stack), pool-fills are episodically destroyed and then rebuilt in the resulting void; thus the flood record lengthens with time since the last major flushing event. Their longevity in Sandy Creek gorge points to the absence of such floods over current storage terms.

\section{Pool-fills and palaeoflood hydrology}

Large floods in narrow, steep bedrock valleys form deep flows that generate extreme hydraulic phenomena such as macro-turbulence, boulder transport and very high flow velocity (Matthes, 1947; Baker, 1977, 1984). Floods of greater than 10-year recurrence perform most of the geomorphic work, because coarse bed materials have high thresholds of mobility (Wolman \& Miller, 1960; Baker, 1977). The effects of extreme floods along Sandy Creek gorge are consistent with those reported from bedrock-confined valleys elsewhere: broad-scale erosion through constrictions coupled with boulder deposition on coarse-grained riffles and floodplains where stream power falls below critical thresholds required for maintaining sediment transport (e.g. Stewart \& LaMarche, 1967; Baker, 1977, 1984). From the analysis of pool-fills and floodplain sequences along Sandy Creek, such catastrophic floods occur with a frequency of $c$. $10^{3}-10^{2}$ years.

Key to the interpretation and use of pool-fills for palaeoflood hydrology is recognizing that valley confinement is linked to a spectrum of sedimentary preservation potential in response to large formative floods. Notwithstanding the 
broad-scale nature of superflood erosion, even superfloods are unlikely to flush valleys completely because of their variable downstream stream power distribution, reflecting the typically irregular morphology of most bedrock rivers (Schick, 1974; Wohl, 1992a,b; Wohl et al., 1994). Eroded and possibly buried remnants of older floodplains may be expected to persist in wider valley reaches providing maximum age constraints on the younger, more frequently reworked sequences found at constrictions. Yet, as in Exit Pool, even constrictions may contain eroded basal remnants, although such materials must be flushed periodically in order to satisfy bedrock channel incision. The question of how, over longer timeframes, the bedrock underlying wider valley sections is eroded remains an important question to be pursued elsewhere.

In Sandy Creek, the modern channel transports a gravelly sand-dominated load $\left(\mathrm{P}_{\mathrm{fm}}\right)$, but at pools lies entrenched within the relict muddy pool-fills $\left(\mathrm{P}_{\mathrm{f}}\right)$ with basal gravelly units $\left(\mathrm{P}_{\mathrm{c}}\right.$ and $\left.\mathrm{P}_{\mathrm{s}}\right)$. These materials now lie buried by actively aggrading sandy benches $\left(\mathrm{B}_{\mathrm{f}}\right)$ that narrow the channel. No evidence exists of bench morphology relating to a regular inundation frequency, consistent with Cohen's (2003) detailed study of benches along the bedrock-controlled Bellinger River, coastal NSW.

Each pool-fill assemblage is shaped by local patterns of flow convergence, hydraulic jetting and recirculating eddies. The three idealized pool-fill assemblages (Fig. 12b-d) reflect varying degrees of lateral confinement and thalweg deflection associated with bedrock outcrops, tributary fans, terraces or even coarse-grained floodplains. A semi-predictable array of units is found in Sandy Creek, but the same principle applies more broadly to discontinuous floodplain sequences preserved along bedrock valleys consistent with gross stream power trends (e.g. Magilligan, 1992). Stacking order, morphology and preservation of sedimentary units are consistent between exposures down-valley in Sandy Creek gorge, and alluvial sequences can generally be correlated by lithostratigraphic means, although sedimentary units relating to the same event will differ depending on the local depositional environment. For example, a bouldery floodplain deposit might correlate with an eroded platform in the pool-fills, possibly topped by supraplatform deposits.

Concerning the nature of the erosional process that might be responsible for flushing the poolfills completely, some clue is provided by the inclined basal erosion surfaces in Rockart Pool and Exit Pool (Fig. 7c and h). Rather than occurring in the lowest topographic position, the oldest pool-fill materials lie furthest from the opposing bedrock bend. Although the stratigraphic data are insufficient to speak with confidence, some ancient-looking, calcic-cemented materials recently exposed at Rockart Pool suggest that the oldest materials will also lie close to the separation point in some pools (the asymmetric inclined assemblage type; Fig. 12b). This suggests a combination of forces directed downstream with those emanating laterally from the bedrock bend.

\section{SUMMARY}

The stratigraphic relationships revealed within a series of excavated pool-fills in Sandy Creek gorge show remarkable consistency in stacking order and preservation of units. Five characteristic types of sedimentary unit are defined based on particle size, sedimentary structures, geometry and bounding surface character: (1) coarsegrained bar platform; (2) fine-grained bar supraplatform; (3) fine-grained pool-fill; (4) fine-grained bench; and (5) modern pool-fill. The last unit is attributed to post-settlement increased sediment supply. The changes to pool-fill geometry associated with this unit echo studies of riffle-pool channels elsewhere, which show growth in temporary sediment storage along the pool exit slope (e.g. Lisle \& Hilton, 1992; Lisle, 1999).

Although pool-fill assemblages share some attributes with two other channel-scale sedimentary units associated with recirculating eddies, eddy bars and slackwater deposits, they are principally forced-bars reflecting bedrock-controlled or 'forced' riffle-pool morphology.

The interpretation and use of pool-fills for palaeoflood hydrology involves recognizing that valley confinement drives a spectrum of sedimentary preservation potential in response to large formative floods. Notwithstanding their generally low potential for preservation in the geological record, pool-fills offer potentially useful information on floods of intermediate intensity over the $10^{3}-10^{2}$ a intervals between extreme floods. Flood histories conventionally devised from palaeoflood slackwater analyses tend to relegate intermediate-magnitude events to some secondary role. Yet, such events represent the flood magnitudes most likely to prevail over human life spans, and are thus very informative for management of these steep, high-energy 
channels and their thin and temporary floodplains.

The formation and preservation pattern of these landforms reflects a combination of hydraulic and structural influences, but the occurrence of highmagnitude floods exerts the dominant control.

\section{ACKNOWLEDGEMENTS}

This paper stems from the senior author's doctoral work at the Department of Physical Geography, Macquarie University, and was written during a Postdoctoral Fellowship funded by the Australian Research Council at the School of Geosciences, University of Wollongong. Trish Fanning financed some of the ${ }^{14} \mathrm{C}$ dates reported here, and D. Witter facilitated the archaeological excavations. We are grateful to Paul Carling, Tim Cohen and Doug Thompson for their constructive and insightful reviews. We acknowledge the Traditional Owners of this country.

\section{REFERENCES}

Ager, D.V. (1973) The Nature of the Stratigraphical Record. Macmillan Press, London.

Baker, V.R. (1977) Stream-channel response to floods, with examples from central Texas. Geol. Soc. Am. Bull., 88, 1057-1071.

Baker, V.R. (1984) Flood sedimentation in bedrock fluvial systems. In: Sedimentology of Gravels and Conglomerates (Eds E.H. Koster and R.J. Steel), Can. Soc. Petrol. Geol. Mem., 10, 87-98.

Baker, V.R. (1989) Magnitude and frequency of paleofloods. In: Floods, Their Hydrological, Sedimentological, and Geomorphological Implications (Eds K. Beven and P.A. Carling), pp. 171-183. Wiley and Sons, New York.

Baker, V.R. and Pickup, G. (1987) Flood geomorphology of the Katherine Gorge, Northern Territory, Australia. Geol. Soc. Am. Bull., 98, 635-646.

Baker, V.R., Kochel, R.C., Patton, P.C. and Pickup, G. (1983) Paleohydrologic analysis of Holocene flood slack-water sediments. In: Modern and Ancient Fluvial Sediments (Ed. J.D. Collinson), IAS Spec. Publ., 6, 229-239.

Beadle, N.C.W. (1948) The Vegetation and Pastures of Western New South Wales with Special Reference to Soil Erosion. NSW Govt Printer, Sydney.

Blong, R.J. and Gillespie, R. (1972) Fluvially transported charcoal gives erroneous C-14 ages for recent deposits. Nature, 271, 739-741.

Bowman, D. (1977) Stepped-bed morphology in arid gravelly channels. Geol. Soc. Am. Bull., 88, 291-298.

Brierley, G.J. (1991) Bar sedimentology of the Squamish River, British Columbia: definition and application of morphostratigraphic units. J. Sed. Petrol., 61, 211-225.

Brierley, G.J. (1996) Channel morphology and element assemblages: a constructivist approach to facies modelling. In: Advances in Fluvial Dynamics and Stratigraphy (Eds
P.A. Carling and M.R. Dawson), pp. 263-298. J. Wiley and Sons, Chichester.

Brierley, G.J. and Hickin, E.J. (1985) The downstream gradation of particle sizes in the Squamish River, British Columbia. Earth Surf. Proc. Land., 10, 597-606.

Bureau of Meteorology (1988) Climatic Atlas of Australia. Australian Govt Publ. Service, Canberra.

Carling, P.A. (1987) Hydrodynamic interpretation of a boulder berm and associated debris-torrent deposits. Geomorphology, 1, 53-67.

Carling, P.A. (1989) Hydrodynamic models of boulder berm deposition. Geomorphology, 2, 319-340.

Carling, P.A. (1995) Flow-separation berms downstream of a hydraulic jump in a bedrock channel. Geomorphology, 11, 245-253.

Cenderelli, D.A. and Cluer, B.L. (1998) Depositional processes and sediment supply in resistant boundary channels: examples from two case studies. In: Rivers Over Rock: Fluvial Processes in Bedrock Channels (Eds K.J. Tinkler and E.E. Wohl), AGU Geophys. Monogr., 107, 105-132.

Chin, A. (1998) On the stability of step-pool mountain streams. J. Geol., 106, 59-69.

Church, M., McLean, D.G. and Wolcott, J.F. (1987) River bed gravels: sampling and analysis. In: Sediment Transport in Gravel-Bed Rivers (Eds C.R. Thorne, J.C. Bathurst and R.D. Hey), pp. 43-79. J. Wiley and Sons, Chichester.

Cohen, T.J. (2003) Late Holocene floodplain processes and post-European channel dynamics in south-eastern Australia. Unpubl. PhD Thesis, University of Wollongong, Wollongong.

Dolan, R., Howard, A.D. and Trimble, D. (1978) Structural control of the rapids and pools of the Colorado River in Grand Canyon. Science, 202, 629-631.

Dunkerley, D.L. (1992) Channel geometry, bed material and inferred flow conditions in ephemeral stream systems, Barrier Range, western NSW, Australia. Hydrol. Process., 6, 417-433.

Dury, G.H. (1970) A re-survey of part of the Hawkesbury River, New South Wales, after one hundred years. Aust. Geogr. Stud., 8, 121-132.

Erskine, W.D. and Livingstone, E.A. (1999) In-channel benches: the role of floods in their formation and destruction on bedrock-confined rivers. In: Varieties of Fluvial Form (Eds A.J. Miller and A. Gupta), pp. 445-475. Wiley, Chichester.

Fanning, P.C. (1984) Erosion and sedimentation along Homestead Creek at Fowler's Gap NSW. Unpubl. MSc Thesis, University of New South Wales, Sydney.

Fanning, P.C. (1999) Recent landscape history in arid western New South Wales, Australia: a model for regional change. Geomorphology, 29, 191-209.

Graeme, D. and Dunkerley, D.L. (1993) Hydraulic resistance by the river red gum, Eucalyptus camaldulensis, in ephemeral desert streams. Aust. Geogr. Stud., 31, 141-154.

Graf, W.L. (1979) Rapids in canyon rivers. J. Geol., 87, 533-551.

Grant, G.E., Swanson, F.J. and Wolman, M.G. (1990) Pattern and origin of stepped-bed morphology in high gradient streams, Western Cascades, Oregon. Geol. Soc. Am. Bull., 102, 340-352.

Hickin, E.J. (1969) A newly-identified process of point bar formation in natural streams. Am. J. Sci., 267, 999-1010.

Howard, A.D. and Dolan, R. (1981) Geomorphology of the Colorado River in the Grand Canyon. J. Geol., 89, 269298. 
Jackson, W.L. and Beschta, R.L. (1982) A model of two-phase bedload transport in an Oregon Coast Range stream. Earth Surf. Proc. Land., 7, 517-527.

Jansen, J.D. (2001) Bedrock channel morphodynamics and landscape evolution in an arid zone gorge. Unpubl. $\mathrm{PhD}$ Thesis, Macquarie University, Sydney.

Keller, E.A. and Melhorn, W.N. (1978) Rhythmic spacing and origin of pools and riffles. Geol. Soc. Am. Bull., 89, 723-730.

Kieffer, S.W. (1985) The 1983 hydraulic jump in Crystal Rapid: implications for river-running and geomorphic evolution in the Grand Canyon. J. Geol., 93, 385-406.

Kieffer, S.W. (1989) Geologic nozzles. Rev. Geophys., 27, 3-38.

Kinoshita, R. and Miwa, H. (1974) River channel formation which prevents downstream translation of transverse bars. Shinsabo, 94, 12-17 (in Japanese).

Kochel, R.C. and Baker, V.R. (1988) Paleoflood analysis using slackwater deposits. In: Flood Geomorphology (Ed. V.R. Baker, R.C. Kochel and P.C. Patton), pp. 357-376. Wiley, New York.

Kochel, R.C. and Ritter, D.C. (1987) Implications of flume experiments on the interpretation of slackwater paleoflood sediments. In: Regional Flood Frequency Analysis (Ed. V.P. Singh), pp. 371-390. Reidel, Boston.

Lisle, T.E. (1986) Stabilization of a gravel channel by large streamside obstructions and bedrock bends, Jacoby Creek, northwestern California. Geol. Soc. Am. Bull., 97, 999-1011.

Lisle, T.E. (1999) Fine bed material in pools of natural gravel bed channels. Water Resour. Res., 35, 1291-1304.

Lisle, T.E. and Hilton, S. (1992) The Volume of fine sediment in pools: an index of sediment supply in gravel-bed streams. Water Resour. Bull., 28, 371-383.

Magilligan, F.J. (1992) Thresholds and the spatial variability of flood power during extreme floods. Geomorphology, 5, 373-390.

Matthes, G.H. (1947) Macroturbulence in natural stream flow. Trans. Am. Geophys. Union, 28, 255-265.

Miller, A.J. (1994) Debris-fan constrictions and flood hydraulics in river canyons: some implications from two-dimensional flow modelling. Earth Surf. Proc. Land., 19, 681-697.

Mlynarczyk, Z. and Rotnicki, K. (1989) Flood and vortex scour of the channel bed of the Prosna River, and their depth range. Earth Surf. Proc. Land., 14, 365-373.

Montgomery, D.R. and Buffington, J.M. (1997) Channel-reach morphology in mountain drainage basins. Geol. Soc. Am. Bull., 109, 596-611.

Neef, G., Bottrill, R.S. and Ritchie, A. (1995) Phanerozoic stratigraphy of the northern Barrier Ranges, western New South Wales. Aust. J. Earth Sci., 42, 557-570.

O'Connor, J.E., Webb, R.H. and Baker, V.R. (1986) Paleohydrology of riffle-pool pattern development: Boulder Creek, Utah. Geol. Soc. Am. Bull., 97, 410-420.

O'Connor, J.E., Ely, L.L., Wohl, E.E., Stevens, L.E., Melis, T.S., Kale, V.S. and Baker, V.R. (1994) A 4500-year record of large floods on the Colorado River in the Grand Canyon, Arizona. J. Geol., 102, 1-9.

Ogden, J. (1978) On the dendrochronological potential of Australian trees. Aust. J. Ecol., 3, 339-356.

Page, K. and Nanson, G. (1982) Concave-bank benches and associated floodplain formation. Earth Surf. Proc. Land., 7, 529-543.

Patton, P.C., Baker, V.R. and Kochel, R.C. (1979) Slackwater deposits: a geomorphic technique for the interpretation of fluvial paleohydrology. In: Adjustments of the Fluvial System (Eds D.D. Rhodes and G.P. Williams), pp. 225-253. Kendall/Hunt, Dubuque, IA.
Pickup, G. (1986) Fluvial landforms. In: Australia - a Geography, Volume One: the Natural Environment (Ed. D.N. Jeans), pp. 148-179. Sydney University Press, Sydney.

Pickup, G., Allan, G. and Baker, V.R. (1988) History, palaeochannels and palaeofloods of the Finke River, central Australia. In: Fluvial Geomorphology of Australia (Ed. R.F. Warner), pp. 105-127. Academic Press, Sydney.

Richards, K.S. (1976) The morphology of riffle-pool sequences. Earth Surf. Proc. Land., 1, 71-88.

Rubin, D.M., Schmidt, J.C. and Moore, J.N. (1990) Origin, structure and evolution of a reattachment bar, Colorado River, Grand Canyon, Arizona. J. Sed. Petrol., 60, 982-991.

Schick, A.P. (1974) Formation and obliteration of desert stream terraces - a conceptual analysis. Zeit. Geomorphol. Suppl., 21, 88-105.

Schmidt, J.C. (1986) Changes in alluvial deposits, upper Grand Canyon. In: Proc. Fourth Federal Interagency Sedimentation Conference, Las Vegas, NV, pp. 48-57. Water Resources Council.

Schmidt, J.C. (1990) Recirculating flow and sedimentation in the Colorado River in Grand Canyon, Arizona. J. Geol., 98, 709-724.

Schmidt, J.C. and Graf, J.B. (1990) Aggradation and degradation of alluvial sand deposits, 1965-86, Colorado River, Grand Canyon National Park, Arizona. USGS Prof. Paper, 1493, $100 \mathrm{pp}$

Schmidt, J.C. and Rubin, D.M. (1995) Regulated streamflow, fine-grained deposits, and effective discharge in canyons with abundant debris fans. In: Natural and Anthropogenic Influences in Fluvial Geomorphology, the Wolman Volume (Eds J.E. Costa, A.J. Miller, K.W. Potter and P.R. Wilcock), AGU Geophys. Monogr., 89, 177-195.

Schmidt, J.C., Rubin, D.M. and Ikeda, H. (1993) Flume simulation of recirculating flow and sedimentation. Water Resour. Res., 29, 2925-2939.

Stewart, J.H. and LaMarche, V.C. (1967) Erosion and deposition produced by the flood of December 1964 on Coffee Creek, Trinity County, California. USGS Prof. Paper, 422K, $22 \mathrm{pp}$.

Stuiver, M. and Reimer, P.J. (1993) Extended ${ }^{14} \mathrm{C}$ data-base and revised Calib $3.0{ }^{14} \mathrm{C}$ age calibration program. Radiocarbon, 35, 215-230.

Stuiver, M., Reimer, P.J., Bard, E., Beck, J.W., Burr, G.S., Hughen, K.A., Kromer, B., McCormac, F.G., Plicht, J.v.d. and Spurk, M. (1998) INTCAL 98 Radiocarbon age calibration 24,000-0 cal BP. Radiocarbon, 40, 1041-1083.

Thompson, D.M. (2001) Random controls on semi-rhythmic spacing of pools and riffles in constriction-dominated rivers. Earth Surf. Proc. Land., 26, 1195-1212.

Thompson, D.M., Wohl, E.E. and Jarrett, R.D. (1999) Velocity reversals and sediment sorting in pools and riffles controlled by channel constrictions. Geomorphology, 27, 229-241.

Wainwright, J., Mulligan, M. and Thornes, J. (1999) Plants and water in drylands. In: Eco-Hydrology - Plants and Water in Terrestrial and Aquatic Environments (Eds A.J. Baird and R.L. Wilby), pp. 78-126. Routledge, London.

Wasson, R.J. and Galloway, R.W. (1986) Sediment yield in the Barrier Range before and after European settlement. Aust. Rangelands J., 8, 79-90.

Wohl, E.E. (1992a) Bedrock benches and boulder bars: floods in the Burdekin Gorge of Australia. Geol. Soc. Am. Bull., 104, 770-778.

Wohl, E.E. (1992b) Gradient irregularity in the Herbert Gorge of northwestern Australia. Earth Surf. Proc. Land., 17, 6984. 
Wohl, E.E., Vincent, K.R. and Merritts, D.J. (1993) Pool and riffle characteristics in relation to channel gradient. Geomorphology, 6, 99-110.

Wohl, E.E., Greenbaum, N., Schick, A.P. and Baker, V.R. (1994) Controls on bedrock channel incision along Nahal Paran, Israel. Earth Surf. Proc. Land., 19, 1-13.

Wolman, M.G. (1954) A method of sampling coarse river bed-material. Trans. Am. Geophys. Union, 35, 951-956.
Wolman, M.G. and Miller, J.P. (1960) Magnitude and frequency of forces in geomorphic processes. J. Geol., 68, 54-74.

Manuscript received 15 April 2003;

revision accepted 26 February 2004. 